\title{
De héroe mártir a héroe victorioso: intelectuales peruanos frente al monumento de Francisco Bolognesi y la tesis de un proyecto primitivo para el monumento
}

\section{From martyr hero to victorious hero: Peruvian intellectuals in front of the Francisco Bolognesi monument and the thesis of a primitive project for the monument}

Rafael Dias Scarelli ${ }^{1}$

Universidade de São Paulo

1 Magíster en historia social de la Universidade de São Paulo, cuya tesis se titula Nos altares da pátria: Monumento al Combate Dos de Mayo e Monumento a Francisco Bolognesi em Lima (1866-1924). Becario de la FAPESP y CAPES. Código ORCID: 0000-0002-6103-6539

Contacto: rafael.scarelli@usp.br. Master's student at the University of São Paulo, supported by FAPESP and CAPES; grant\#2017/05623-7, São Paulo Research Foundation (FAPESP). The opinions, hypotheses, conclusions or recommendations contained in this material are the sole responsibility of the author and do not necessarily reflect FAPESP/ CAPES opinion. Agradezco a la profesora Dra. Carlota Casalino Sen (UNMSM), que me recibió para una estancia de investigación entre septiembre y noviembre de 2018, al profesor Dr. Fernando Villegas Torres (PUCP), que me brindó inestimable apoyo en mi investigación sobre el monumento de Bolognesi, al profesor Dr. Gabriel Ramón Joffré (PUCP), cuya tesis de maestría despertó mi primer interés por la historia limeña, y al Archivo y Biblioteca del Instituto Riva-Agüero, donde hice parte importante de mi investigación. Agradezco también a mi orientadora de posgrado, profesora Dra. Gabriela Pellegrino Soares (USP). 
De héroe mártir a héroe victorioso: intelectuales peruanos frente al monumento de

Francisco Bolognesi y la tesis de un proyecto primitivo para el monumento

\section{Resumen}

Se presentan los posicionamientos de intelectuales y artistas peruanos frente al monumento del coronel Francisco Bolognesi en dos contextos separados por casi medio siglo: la inauguración (1905) y el reemplazo de la estatua del héroe (1954). Se busca comprender cómo se desarrolló el cambio de sensibilidad de mártir a héroe victorioso respecto al coronel de Arica, lo que legitimó la sustitución de la obra escultórica. Se propone que la imagen de héroe-mártir plasmada en la primera escultura ya era indeseada en la mitad del siglo pasado, frente a la definición de las provincias "cautivas" de Tacna y Arica, el suceso militar peruano en la campańa contra Ecuador (1941) y la promoción de Bolognesi a patrono del Ejército. Además, se refuta la difundida tesis de que hubo un "proyecto primitivo" para el monumento del escultor catalán Agustín Querol, que no se concretizó por intervención de la comisión organizadora del concurso. Se busca interpretar su surgimiento y difusión a luz del contexto de los años 50 , cuando se intentaba descalificar la escultura hecha por Querol.

Palabras clave: monumento de Francisco Bolognesi, monumentos públicos, intelectuales, artistas, nacionalismo, Lima, siglo 20

\section{Abstract}

The positions of Peruvian intellectuals and artists upon the monument to Colonel Francisco Bolognesi are presented in two contexts separated for nearly half a century: the inauguration in 1905 and the replacement of the statue of the hero in 1954. The aim is to understand how the change of sen- 
sibility from martyr to victorious hero was developed with respect to the colonel of Arica, which legitimized the substitution of the sculptural work. It is proposed that the image of hero-martyr represented in the first sculpture had already became unwanted in the middle of the last century, because of the definition of the "captive" provinces of Tacna and Arica dispute, the Peruvian military triumph against Ecuador (1941) and the promotion of Bolognesi as a patron of the Peruvian Army. In addition, the widespread thesis that there was an "primitive project" for the monument, by the Catalan sculptor Agustín Querol, which did not materialize due to the intervention of the organising committee of the competition, is refuted. An interpretation is sought regarding the emergence and dissemination of the "primitive project" in the light of the context of the 1950s, when an attempt was made to disqualify the sculpture made by Querol.

Key words: Francisco Bolognesi monument, public monuments, intellectuals, artists, nationalism, Lima, XX century

\section{Introducción}

"Artículo de exportación ultramarina", "lección de heroísmo y belleza", "parece borracho", fueron algunas de las frases dichas por intelectuales y artistas peruanos delante de la escultura dedicada al coronel Francisco Bolognesi, inaugurada en Lima en noviembre de 1905. Este fue uno de los monumentos públicos limeños que más movilizó y polarizó opiniones, expresadas en un folleto y un libro, y en artículos de periódicos y revistas. 
En este trabajo, analizo panorámicamente la movilización y los posicionamientos de esos intelectuales frente al monumento y busco interpretar el paso de héroe mártir a héroe victorioso del coronel Bolognesi. Mi análisis se concentra en dicha obra, a fin de descifrar cómo el cambio de sensibilidad respecto al coronel se proyectó sobre su escultura y legitimó su sustitución en 1954. Además, confronto la tesis de que hubo un "proyecto primitivo” del escultor catalán Agustín Querol (1860-1909), presentado a la comisión organizadora del certamen con anterioridad y rechazado por su elevado costo.

Maurice Agulhon, cuyos trabajos se constituyen en referencias clásicas del tema de la estatuaria, designó de statuomanie la multiplicación de monumentos públicos en Francia durante la Tercera República, entre los años de la guerra francoprusiana (1870) y la Primera Guerra Mundial (1914). Para explicar el fenómeno, el autor argumentó que, a diferencia de las experiencias republicanas de 1792 a 1848, la Tercera República desfrutó de mayor tiempo para transferir del yeso al mármol o bronce sus proyectos (Agulhon, 1988, pp. 128-129). Señala también la propia moral liberal, laica y humanista de la república, abierta a homenajear en el espacio público a los hombres ordinarios que no participaban de la sacralidad religiosa ni monárquica, un privilegio reservado a los reyes y los santos hasta entonces (Agulhon, 1988, p. 143).

Asimismo, Agulhon argumentó que la Tercera República, nacida de una dolorosa experiencia de derrota en la guerra franco-prusiana, no se eximió de rendir tributo a sus combatientes que perecieron en el conflicto. Así que el régimen no nació solamente de la derrota, sino del honor de haber intentado vencer a la derrota (Agulhon 1988, p. 130). Para Eric Hobsbawm (2012, p. 347), estos fueron años de intensa 
"fabricación de tradiciones" en Francia, que tuvieron como instrumentos la construcción de monumentos -frecuentemente, vectores para la representación de la imagen de la Marianne, alegoría de la república francesa-, la difusión de la enseñanza primaria -como equivalente secular de la iglesiay las grandes celebraciones, como el Día de la Bastilla.

Sin embargo, más que rendir justo tributo a la memoria de los muertos, estaba en cuestión para los franceses de antaño la lucha por recuperar de Alemania sus provincias perdidas en la guerra, Alsacia y Lorena. Cabe recordar el relato del militar francés Robert Poustis (Arthur, 2002), que luchó en las trincheras de la Primera Guerra Mundial, respecto a su niñez: sea en el ambiente familiar o escolar, se hablaba con pesar de la pérdida de las dos provincias y en los mapas escolares, dichas regiones eran marcadas con colores especiales, para realzarlas y estimular el deseo de recuperarlas (Stancik, 2003, pp. 219-244). Vemos que no solamente las victorias, sino también las derrotas militares son capaces de promover el sentimiento nacionalista alrededor del deseo de revancha o de reivindicación por recuperar territorios perdidos.

En el Perú, sucedió un proceso análogo después de la guerra del Pacífico (1879-1883) y la ratificación del Tratado de Ancón (1884). Dicho tratado, resultó en la pérdida definitiva de la provincia meridional de Tarapacá y en la concesión temporal a Chile de las provincias de Tacna y Arica por diez años, al cabo de los cuales debería ocurrir un plebiscito para definir su futuro. Frente a no realización del plebiscito y de la campaña de chilenización de la zona en litigio promovida por Chile, el Perú se lanzó en una campaña para recuperar sus pretendidos territorios. 
De héroe mártir a héroe victorioso: intelectuales peruanos frente al monumento de Francisco Bolognesi y la tesis de un proyecto primitivo para el monumento

No es casualidad que el primer monumento público de gran envergadura, construido en la capital peruana después de la guerra, haya sido dedicado a los mártires de la batalla de Arica, que tuvo lugar el 7 de junio de 1880 en uno de los territorios reclamados por el Perú, y cuyo resultado, la derrota peruana, permitió la ocupación chilena de la zona. Afirmar el heroísmo de sus combatientes y, en especial, del coronel que lideró la batalla, Francisco Bolognesi (1816-1880), subrayando su rechazo a la oferta de rendición chilena, era fundamental en los discursos que buscaban realzar la justicia de la reivindicación peruana. Aunque el punto de partida de ese monumento no haya sido una iniciativa del Estado peruano, sino de un grupo de estudiantes colegiales limeños que organizaron la Asamblea Escolar en 1888 (Cisneros, 1905), es necesario aclarar la adhesión del Gobierno y de la Municipalidad de Lima al proyecto, que asumió la gestión y financiamiento de la mayor parte de la obra²

Como ya señaló Rodolfo Monteverde Sotil (2017, pp. 664665), el Gobierno peruano buscó en esos años acercarse a Argentina para contar con el apoyo rioplatense en las negociaciones de frontera con Chile, como sucedería algunos años después con relación a Bolivia, que resultaría en el tratado

2 Al respecto, Monteverde Sotil (2017, pp. 668-669) señala que los proyectos escultóricos del periodo posguerra tuvieron su punto de partida en iniciativas particulares, como el monumento a Grau (1897) en el Callao, cuya subscripción pública fue iniciada por el empresario Peter Bacigalupo, y el monumento a San Martín (1906) donado por Lorenzo Pérez Roca. El Gobierno había optado por homenajes menos individualizados, sea por la deteriorada situación económica del erario al final del conflicto, sea por la necesidad de esperar el plazo para el plebiscito en Tacna y Arica previsto para 1894 a fin de definir los contornos del discurso oficial sobre la guerra. 
de 1909 entre los dos países andinos. La invitación especial para la solemne fiesta de inauguración del monumento en noviembre de 1905 y el paso del estadista argentino Roque Sáenz Peña (1851-1914) -que no solo había luchado en la batalla de Arica, sino que también había tomado parte en el consejo de guerra reunido por Bolognesi, que decidiera rehusar la rendición-, deben ser entendidos como parte de ese esfuerzo. Roque Sáenz Peña, después de su participación en la guerra, volvió a Argentina y tuvo destacada actuación política y diplomática, y fue el delegado argentino en las conferencias panamericanas de Washington (1889-1890) junto a Manuel Quintana y el Ministro de Relaciones Exteriores Juárez Celman en 1890, siendo su padre Luis Sáenz Peña presidente del país entre 1892 y 1895, hechos que sin duda resaltan la figura del excombatiente argentino de Arica. Por todo eso, la construcción del monumento a Bolognesi no puede ser mirada fuera del contexto geopolítico de la posguerra del Pacífico.

Alfonso Castrillón Vizcarra (1991) en su panorámica obra destinada a analizar los monumentos públicos y funerarios de Lima presentó una de las primeras investigaciones sobre el monumento a Bolognesi, apoyándose, entre otras fuentes, en la Memoria de la Municipalidad de Lima de 1902 (1903), aunque se equivoque al afirmar el año de inauguración del monumento en 1906 (p. 341). Destaco también el trabajo de Fernando Villegas Torres (2015), derivado de su tesis doctoral, que revisó el más consiste conjunto documental respecto a la erección del monumento e identificó las bases del concurso y las etapas de construcción de la obra. Virgilio Cabanillas Delgadillo (2017) se concentró en el análisis comparado de los trabajos del escultor Querol, considerando sus proyectos anteriores -apoyándose, especialmente, en los aportes de Ro- 
De héroe mártir a héroe victorioso: intelectuales peruanos frente al monumento de Francisco Bolognesi y la tesis de un proyecto primitivo para el monumento

drigo Gutiérrez Viñuales (2003, pp. 355-366)-, mientras que Rodolfo Monteverde Sotil (2017) iluminó el contexto geopolítico de la construcción e inauguración de la obra.

Empero, todavía no hay trabajos que analicen con mayor profundidad el proceso de reemplazo de las estatuas, el cambio de sensibilidad respecto a la imagen del héroe, ni las estrategias desplegadas para legitimarlo.

\section{La representación del héroe moribundo y el monumento a Bolognesi}

Frente a la proximidad temporal de la derrota $-\mathrm{o}$, por lo menos, a la prolongación de sus consecuencias, con la indefinida situación de las provincias "cautivas"- y a la muerte de los principales jefes militares, Bolognesi y muchos de sus compañeros fueron incorporados en el panteón nacional como héroes-mártires en un primer momento. Asimismo, el coronel José Gálvez (1819-1866), homenajeado en el monumento del Dos de Mayo (1874), dedicado al combate del Callao (1866) -conflicto vencido por el Perú contra la escuadra española, en que el coronel Gálvez perdió la vida-, ya había sido incorporado en la misma clave del martirio. De esa manera, en los dos monumentos los héroes aparecieron en posición corporal agónica y desfallecida, en los últimos instantes antes de la muerte. En la tradición de representación visual de los héroes nacionales, un antecedente se encuentra en el lienzo de José Gil de Castro, que representa al pescador indígena chorrillano José Olaya ${ }^{3}$, mártir de las guerras de in-

3 José Gil de Castro, José Olaya (1828), 204 x 137 cm, Museo Nacional de Arqueología, Antropología e Historia del Perú, Ministerio de Cultura del Perú. 
dependencia del Perú, retratado de cuerpo entero en trajes blancos (Barentzen Gamarra, 2010, pp. 173-192; Mondoñedo Murillo, 2002).

La representación de combatientes moribundos, -caídos de rodillas o tumbados, con los ojos cerrados o en otras posiciones que remiten a la hora de la muerte- se vincula a una larga tradición escultórica que tiene sus raíces en la Antigüedad. Muchas son las estatuas romanas dedicadas a los "gladiadores moribundos" moribundo fue objeto de múltiples reproducciones desde su aparición en el siglo XVII (Haskell y Penny, 2006, pp. 226227).

La imagen del mártir fue potenciada en la Edad Moderna con las representaciones religiosas de martirios de santos y la crucifixión de Cristo, entre las cuales la Pietà de Michelangelo es un ejemplo sobresaliente en la escultura. En el ámbito de la estatuaria moderna, las imágenes de héroes heridos o muertos aparecieron en monumentos, como el de Ercole Rosa a los hermanos Cairoli (1883) - homenaje a Enrico y Giovanni Cairoli, que combatieron en la campaña por libertar Roma de los Estados papales, apoyados por las fuerzas de Napoleón III-, además de las obras del mismo Agustín Querol, como el monumento a los Mártires de la Religión y de la Patria de Zaragoza (1901), inspirado en el anterior monumento a los Bomberos de la Habana (Gutiérrez Vińuales, 2004, p. 218). Dicha representación ha ganado más proyec-

4 Para imágenes de estas esculturas, véase la enciclopedia Warbourg - Banco Comparativo de Imagens, del Centro de História da Arte e Arqueología de la Universidad Estadual de Campinas (Unicamp): https://www.unicamp. br/chaa/warburg.php Consultado 21.06.2019. 
ción en los homenajes a los muertos de la Primera Guerra Mundial, a ejemplo de los "monumenti ai caduti" que se erigieron en casi todas las comunas italianas financiados por las autoridades o subscriciones públicas, como señaló Sandra Berresford (2007).

Antoine Prost (1982, pp. 195-225), en la monumental colección Les lieux de mémoire, analiza los monumentos construidos en Francia en memoria de los muertos de la grande guerra. Aunque reconozca la diversidad de memoriales a los muertos - la mayoría compuesta por estelas acompañadas de antorchas funerarias y cruces sin esculturas-, Prost identifica, entre los monumentos que exhiben la figura de soldados, un tipo específico de estatuas que no suelen representarse en pose triunfante. Por el contrario, en estas obras los poilu -designación para los soldados franceses de infantería de la Primera Guerra Mundial-, aparecen a menudo moribundos, con el cuerpo desfallecido, aunque muchas veces de pie, abrazados a la bandera o apretándola contra su pecho sirviéndoles de mortaja.

En composición muy semejante a la que vemos en el Bolognesi de Querol, está el monumento a los Muertos de Craon (Mayenne $)^{5}$, hecho en mármol de Carrara e inaugurado en 1921, que exhibe a un combatiente de pie con las rodillas 64 flexionadas, agarrándose a la bandera patria (figura 1). Sigue la misma composición el monumento funerario-patriótico de Margny-sur-Matz (Oise), reproducido por Prost. Estos

5 Sobre dicho monumento, véase la página de la Université de Lille, "Les Monuments aux Morts. France, Belgique, Autres Pays": https://monumentsmorts.univ-lille.fr/monument/5414/craon-place/

Consultado: 21.06.2019. 
monumentos franceses a la guerra de 1914-1918, aunque sean obras de contextos distintos, presentan puntos de contacto con el monumento a Bolognesi de Querol: héroes heridos, de pie, pero con el cuerpo inclinado, sosteniendo la bandera y, frecuentemente, un revólver, pero no en posición de conflicto ni de triunfo.

Prost vincula dicha representación a una tradición conservadora, en la que "la patria, como Dios, se convierte en una realidad transcendente, que justifica el sacrificio que se convierte, estrictamente hablando, en martirio, testimonio, acto

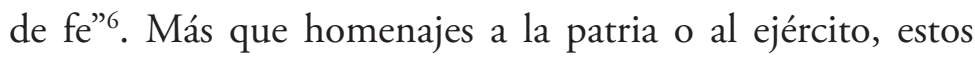
monumentos homenajean a los muertos y a su sacrificio -individualizándolos con inscripciones nominales, como ocurre en el monumento del Dos de Mayo -.

6 En el original: "Dans cette tradition conservatrice, la Patrie, comme Dieu, devient une réalité transcendante, et elle justifie le sacrifice qui devient à proprement parler martyre, témoignage, acte de foi”. 
De héroe mártir a héroe victorioso: intelectuales peruanos frente al monumento de Francisco Bolognesi y la tesis de un proyecto primitivo para el monumento

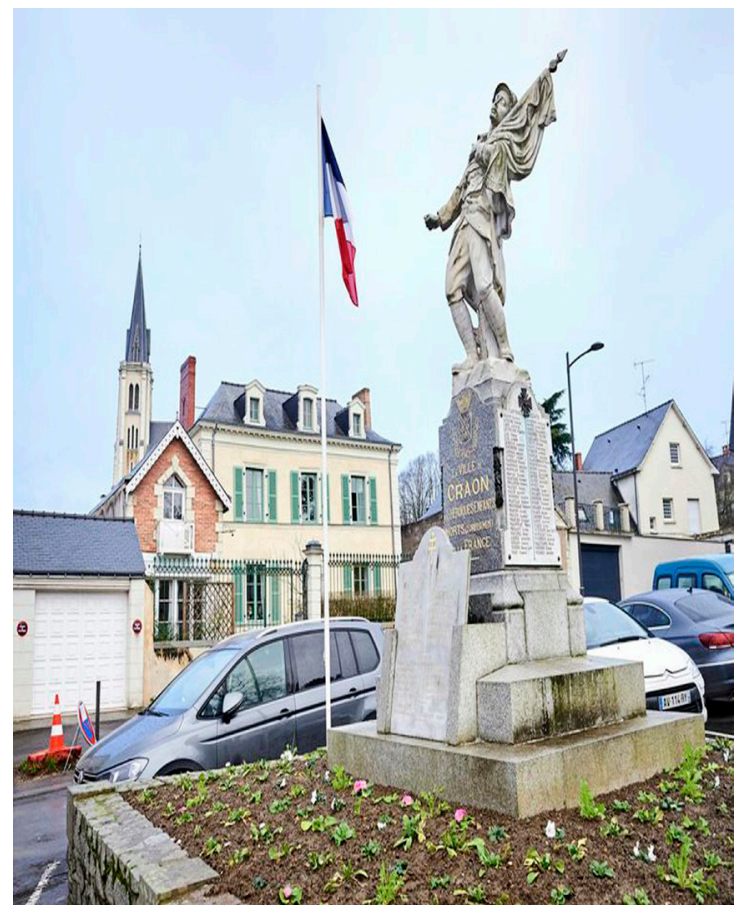

Figura 1. Monumento a los muertos de Craon. Fotografía: Thierry Pasquet. En: Pierre-Henri Allain. "Lactalis. La ville de Craon a cran". Libération, https:// www.liberation.fr/france/2018/01/16/lactalis-la-ville-de-craon-a-cran_1622784

El monumento a Bolognesi, hecho por el escultor catalán Agustín Querol (1860-1909), dialoga con la imagen de héroe-mártir construida para Bolognesi al terminar la guerra.

66 Dicha imagen de mártir se plasmó, simultáneamente, en los planos iconográfico -a través de las pinturas de Juan Lepia$\mathrm{ni}^{7}$ - y literario - por medio de los numerosos textos escolares

7 Hablo de las dos pinturas históricas de Juan Lepiani, La respuesta (1894) y El último cartucho (1899). La primera retrata el consejo de guerra liderado por Bolognesi rechazando la oferta de rendición chilena presentada por el emisario Juan de la Cruz Salvo, mientras la segunda exhibe al héroe 
dedicados a los héroes de la guerra contra Chile. Entre estos, el Catecismo patriótico (1885) de Torres empieza así la presentación de Bolognesi:

Bolognesi (Francisco) [...] Sabían que todos tenían que sucumbir: pero sabían también que su martirio tendría imitadores. Tiernos niños, jóvenes del porvenir: que tanta sangre derramada no sea estéril! La promesa del patriotismo fue cumplida hasta el sacrificio, ha dicho un ilustrado escritor tratando del asunto; Arica cayó en poder del enemigo, pero convertida en un inmenso lago de generosa sangre que casi ahogaba al fatigado vencedor (Torres, 1885, p. 103).

La narración del episodio del morro de Arica solía hacer referencia, en los discursos anteriores o contemporáneos a la inauguración, al universo griego, especialmente a la heroicidad de Leónidas y los 300 espartanos en el desfiladero de Termópilas, en su vano esfuerzo por detener a las fuerzas pérsicas ${ }^{8}$. Ellos habían luchado hacia la inescapable muerte, como hicieron Bolognesi y sus pares al rehusar la oferta de rendición chilena. Se preguntó Teobaldo Elías Corpancho, "La Grecia de Simónides, jamás vió [sic] igual campaña. ¿Acaso las Termópilas eclipsan nuestra hazaña?” (Corpancho, 1905). A su

en el campo de batalla, caído y a punto de ser muerto por el enemigo, sosteniendo con su brazo extendido su revólver (Saldaña Niño, 2018). Ambas fueron incorporadas, como relieves de bronce, en el pedestal del monumento hecho por Agustín Querol.

8 Como señaló César Fornis (2013), las Historias de Heródoto consagraron en el siglo $\mathrm{V}$ a.C. el sentido del honor y deber de los espartanos en Termópilas, rescatados por la Revolución Francesa en su culto a la Antigüedad, alcanzando su representación visual en la pintura de Jacques-Louis David, Léonidas aux Thermopyles (1814). Citando a MacGregor, Fornis habla de una "Edad de Leónidas" entre los siglos XVIII y XIX, cuando el héroe espartano se convirtió en poderoso símbolo de virtud, cuyo sacrificio a la patria debería inspirar los ciudadanos (Fornis, 2013, p. 494). 
De héroe mártir a héroe victorioso: intelectuales peruanos frente al monumento de

Francisco Bolognesi y la tesis de un proyecto primitivo para el monumento

vez, José Santos Chocano proclamó:

Si su esfuerzo fué [sic] el último cartucho,/ Bolognesi fué [sic] el último espartano!/ Hoy canta, ¡o musa! cual cantara un día/ la musa de Simónides la suerte/ de los que hallaron, en la lucha impía/ de las mismas Termópilas, la muerte./ Y di también como ella ante la fría/ tumba del héroe que escalara el cielo:/ «- Su tumba es un altar; y su memoria/ vive en la patria con perenne duelo/ y su duelo es un canto de victoria » $[\ldots]$

Expuesto en las desnudas soledades,/ no de un desfiladero en las guaridas,/ soporta las sangrientas tempestades/ ipor eso en que la voz de las edades/ lo aclamará más grande que Leónidas!... (Chocano, 1900, pp. 184-185, 203).

El monumento (figura 2) se compone de un pilar de granito, rodeado por cuatro grupos alegóricos en bronce: la Fe en la cara frontal, la Historia en la cara posterior, Alfonso Ugarte y su caballo en la cara lateral derecha, soldados defendiendo la bandera en la cara lateral izquierda. Completa el pilar un capitel en mármol, donde se exhiben alegorías de la Fama con su trompeta y de la Gloria extendiendo la corona de laureles?. La estatua de Bolognesi, en la cúspide, solía aparecer de pie, pero con las rodillas dobladas, la cabeza cayendo sobre su pecho, los ojos cerrados.

9 Los grupos alegóricos aquí señalados fueron descritos en el periódico limeño El Comercio y en la revista ilustrada Actualidades, en el contexto de la inauguración (El Comercio 5 de noviembre de 1905, p. 3; Actualidades, noviembre de 1905). 


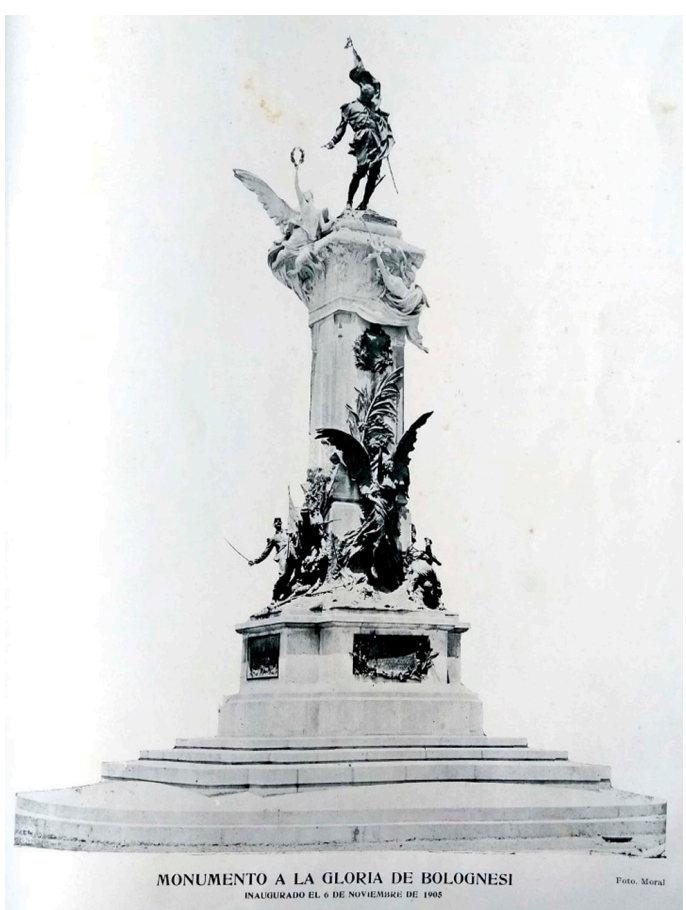

Figura 2. Estatua de Francisco Bolognesi. Prisma, 1905, pp. 38-39

Empero, no solamente la estatua del héroe estaba en posición de martirio en el monumento; entre los soldados de la cara lateral izquierda, vemos a un combatiente herido arrodillado, mientras el coronel Alfonso Ugarte (1847-1880) y su caballo, en la cara lateral derecha, aparecen en posición casi horizontal. Este coronel, según la leyenda de la batalla, se había lanzado del morro con su caballo al verse rodeado por los enemigos -martirio representado en la pintura de Ludovico Agostino Mazzarini Visconti, de 1906. A los pies de la estatua de la Historia, en la cara posterior del pilar, se ve también a un soldado muerto caído en suelo. Se nota que la idea del martirio se manifiesta en todos los grupos escultóricos del monumento. 
De héroe mártir a héroe victorioso: intelectuales peruanos frente al monumento de Francisco Bolognesi y la tesis de un proyecto primitivo para el monumento
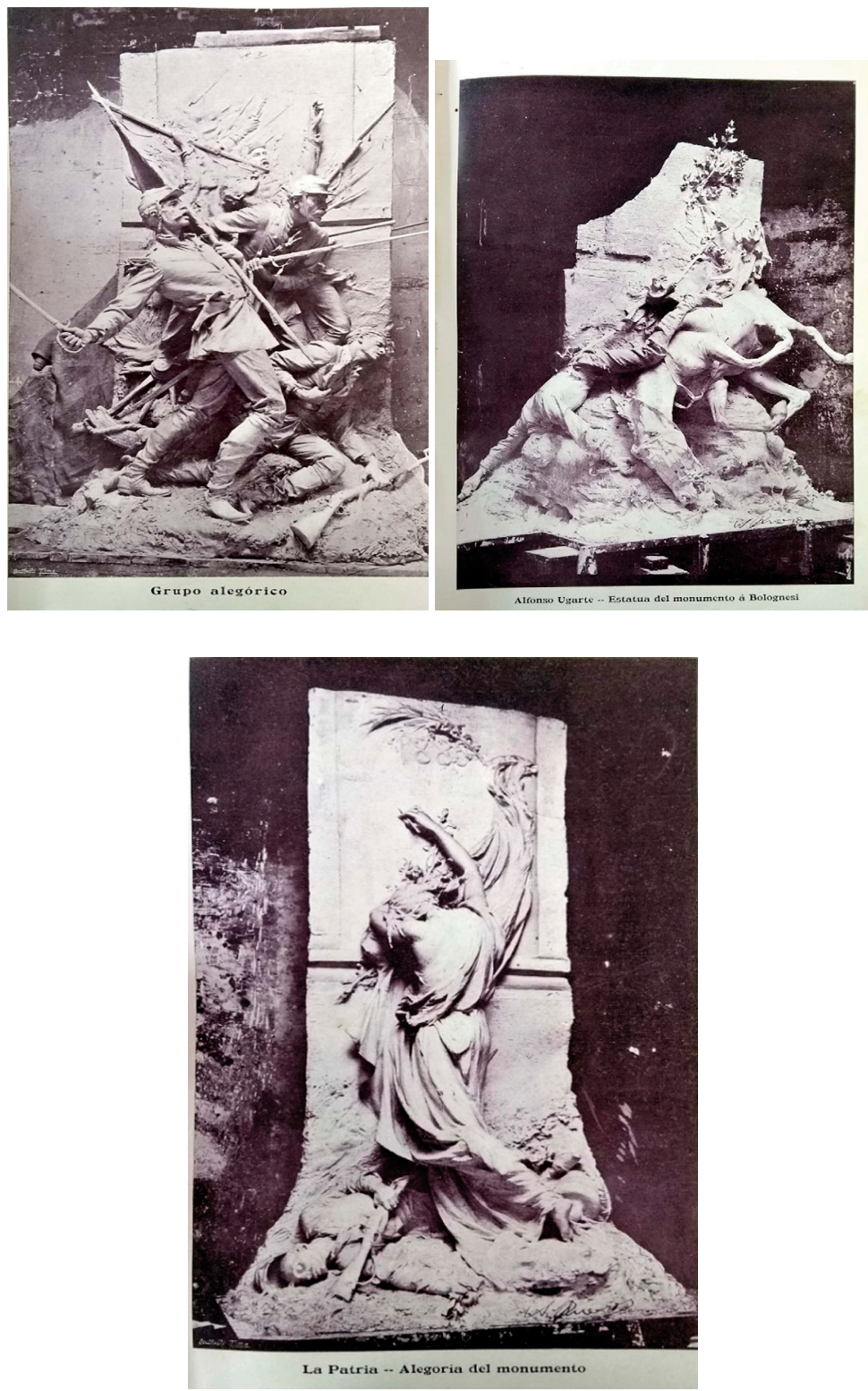

Figuras 3, 4 y 5 . Soldados defendiendo la bandera; Alfonso Ugarte y su caballo; la Historia. Actualidades, 7 de junio de 1904 


\section{Primer acto: la inauguración}

Las fiestas de inauguración del monumento, en noviembre de 1905, se constituyeron en la ocasión privilegiada para la manifestación de los intelectuales peruanos acerca de la obra de Querol. En primer lugar, debido a las dimensiones asumidas por la ceremonia y su preparación, que contó con la presencia de altas autoridades del Estado, además de la participación especial del futuro presidente argentino Roque Sáenz Peña ${ }^{10}$ y su familia, que prestó aires apoteósicos al evento.

En segundo lugar, el exhaustivo trabajo de la prensa peruana en noticiar y comentar el evento, que llevó a los intelectuales de las redacciones de estos medios a manifestarse. La revista Actualidades dedicó un número extraordinario completo y los otros dos números siguientes, el 11 y 18 de noviembre de 1905, al monumento y sus temas correlatos, incluidos el escultor, la biografía del héroe, la batalla, etc. La revista Prisma comentó las fiestas en un número extraordinario de 92 páginas (Prisma, 1905). El diario La Prensa resaltó la inauguración en una edición especial de 16 páginas (La Prensa, 6 de noviembre de 1905), mientras que El Comercio lo discutió en los números publicados entre los días cuatro y ocho de noviembre, con una edición especial de 16 páginas dedicada a la obra el cinco de noviembre. Este mismo diario publicó una lista detallada de los delegados enviados por los periódicos del interior del país para acompañar la ceremonia en la capital, entre los cuales estaban de Arequipa, El Puerto, La Bolsa, El Pueblo y El Deber; de Puno, El Eco de Puno y El Siglo; de Cuzco, Prensa Unida de Cuzco; de Moquegua, La Reforma; de Tacna, El Morro de Arica, El Tacora y La Voz

10 Roque Sáenz Peña fue presidente de Argentina entre 1910 y 1914. 
De héroe mártir a héroe victorioso: intelectuales peruanos frente al monumento de Francisco Bolognesi y la tesis de un proyecto primitivo para el monumento

del Sur (El Comercio, 4 de noviembre de 1905, p. 1). En las imágenes podemos constatar el espacio dado al monumento y a su inauguración en estas publicaciones.

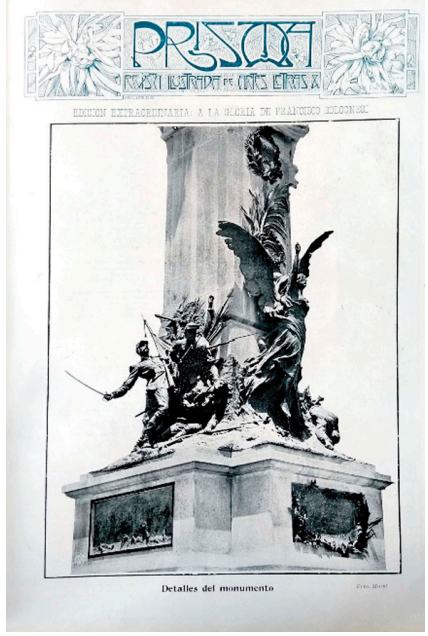

Figura 6. Cubierta de la revista Prima (diciembre de 1905) con el monumento a Bolognesi. Biblioteca Nacional del Perú

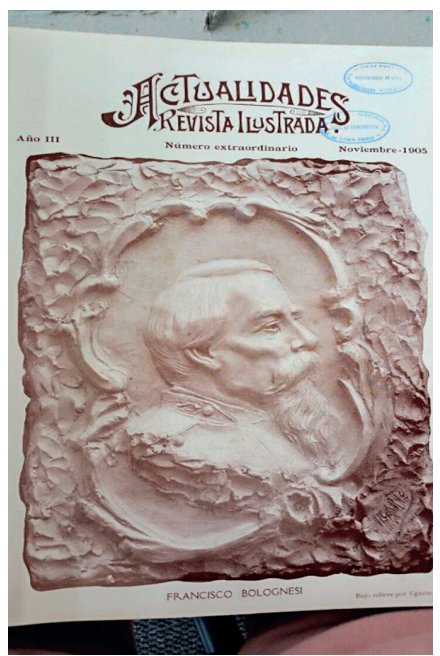

Figura 7. Cubierta de la revista Actualidades (noviembre de 1905) con un retrato de Bolognesi. Biblioteca Nacional del Perú 
Rafael Dias Scarelli

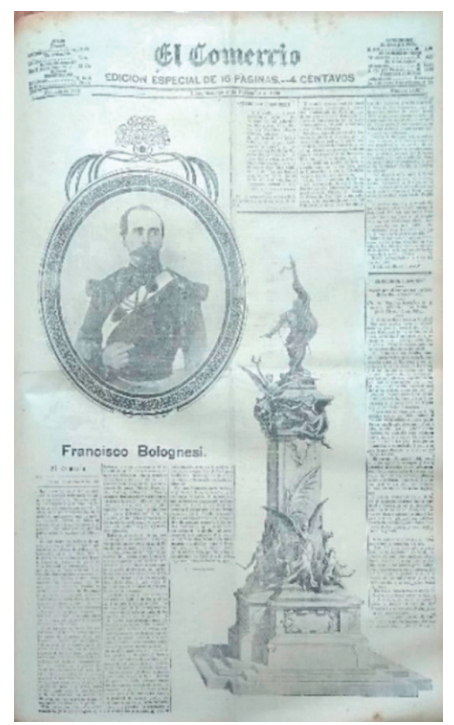

Figura 8. Primera página del diario El Comercio (5 de noviembre de 1905) en la víspera de la inauguración. Aparecen destacados los retratos de Francisco Bolognesi y del monumento. Instituto Riva-Agüero

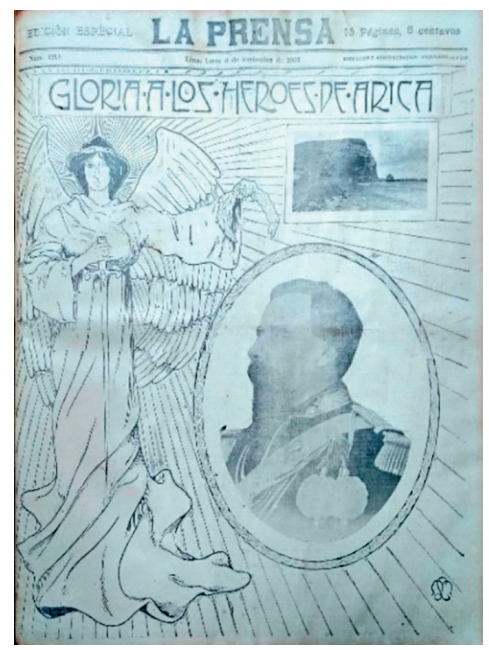

Figura 9. Primera página del diario La Prensa (6 de noviembre de 1905), edición especial de 16 páginas. Aparecen destacadas las imágenes del coronel Bolognesi y del morro de Arica. Instituto Riva-Agüero 
De héroe mártir a héroe victorioso: intelectuales peruanos frente al monumento de Francisco Bolognesi y la tesis de un proyecto primitivo para el monumento

Carlos Altamirano, en la introducción del segundo volumen de Historia de los intelectuales en América Latina, menciona la importancia del periodismo -el "segundo empleo", así como los puestos en la burocracia del Estado- para la inserción en el mundo de las letras y la propia subsistencia de los intelectuales latinoamericanos sin patrimonio familiar, desde principios del siglo XX, a pesar de las horas sustraídas del estudio y de la creación literaria (Altamirano, 2010, p. 14).

Entre los escritores que se manifestaron en estas páginas prevaleció un tono laudatorio a la obra y su autor, elogiada como legítima intérprete de la muerte heroica de Bolognesi. Podemos comprender ese aspecto por la propia postura editorial de estos medios: en ninguna línea, entre las publicaciones citadas se encuentra un comentario crítico al monumento inaugurado. De este conjunto, seleccioné dos autores, que publicaron sus textos en las páginas de la revista Actualidades, que atravesaron la escritura literaria, el periodismo y la diplomacia.

Primero, cito a Enrique A. Carrillo (1877-1936) -conocido por el seudónimo "Cabotín"-, escritor que se destacó en la novela y en la crónica costumbrista ${ }^{11}$. Así se manifestó en $A c$ tualidades:

11 Enrique Carrillo (1877-1936) desde su juventud actuó en el periodismo y dejó colaboraciones en importantes periódicos y revistas limeños como El Diario, El Comercio, La Prensa y Prisma. Destacó en los géneros de la novela, crónica y crítica literaria. Entre las novelas, tuvo notoriedad Cartas de una turista de 1905 (1959). En la crónica, parte de su publicación en periódicos limeños en las primeras décadas del siglo XX fue editada en el libro, Viendo pasar las cosas (1915) (Milla Batres, 1994, p. 71). En 2007, se publicó el libro Obras reunidas, que compiló su obra, con la edición de Miguel Ángel Rodríguez Rea. 
Ha entrevisto Querol, con intuición genial, el postrer episodio de la sublime tragedia, $i$ ha querido perpetuar la memoria del defensor de Arica en el final espasmo de la vida, cuando el cuerpo exhausto se desploma, i el alma, libre de ataduras carnales por proprio $i$ voluntario sacrificio, se remonta á las regiones infinitas. [...] En el noble i austero dolor que se refleja en las facciones del ilustre anciano, se pinta la pasión que le domina i avasalla, el amor sin límites á la bandera, el culto ferviente de la patria, [...], la fe en los posteriores resultados de su lección de heroísmo i de belleza [énfasis agregado] (Carrillo, 1905, p. 23)

Menciono también a Luis Fernán Cisneros (1882-1954), que transitó por el periodismo, la poesía y la diplomacia ${ }^{12}$. En el número extraordinario de Actualidades, el escritor se mostró preocupado en demostrar que el escultor catalán no era el único autor del monumento y merecedor de la corona de laureles: muchos otros fueron sus responsables, desde su idea inicial surgida entre un grupo de estudiantes colegiales limeños que fundaron la Asamblea Escolar liderados por Luis Gálvez- pasando por los trabajos de emplazamiento de la columna por el ingeniero Silgado y el arquitecto Doig, además de las manos de Emilio Díaz en unión de los artesanos Victorino Flórez y Gabino Risco, hasta llegar al pueblo que la recibía:

I [sic] he aquí cómo i [sic] por qué no ha sido Querol el único autor del monumento. I [sic] el pueblo, que rememora

12 Luis Fernán Cisneros (1882-1954) estudió en el Colegio Labarthe y en la Universidad Nacional Mayor de San Marcos. Como periodista, fue redactor y director de La Prensa entre 1904 y 1920 y redactor de $L a ~ N a-$ ción de Buenos Aires entre 1922 y 1933. En la diplomacia, fue ministro en Uruguay (1933-1939), embajador en México (1939-1945) y Brasil (1945-1951), además de delegado en diversas conferencias internacionales. En poesía, es autor de Todo, todo es amor: versos (1923). (Milla Batres, 1994, p. 145). 
De héroe mártir a héroe victorioso: intelectuales peruanos frente al monumento de Francisco Bolognesi y la tesis de un proyecto primitivo para el monumento

la acción guerrera de Bolognesi inmortal i [sic] piensa que desde su altura olímpica dice con su mirada una lección ejemplar á [sic] las generaciones; el pueblo que se descubre con respeto ante la figura broncínea del luchador anciano, no debe olvidar la gestación i [sic] la historia de esta fiesta. Repetirla es hacer justicia á [sic] los nuestros (Cisneros, 1905, p. 12).

Sin embargo, no hubo unanimidad en la recepción a la escultura del héroe. Entre las voces disonantes que se pronunciaron con ocasión de la inauguración de la obra, la más audible fue la de Manuel González Prada (1844-1918) ${ }^{13}$, autor de uno de los primeros ensayos críticos respecto a la condición del indígena en la sociedad peruana, Nuestros indios (1904), que tuvo gran influencia en las generaciones de intelectuales indigenistas de las décadas siguientes, manifiesta en la designación de "Universidad Popular González Prada", experiencia educativa que tuvo entre sus promotores al líder del APRA Víctor Haya de la Torre (Contreras y Cueto, 2013, p. 264).

13 Manuel González Prada (1844-1918) hizo sus primeros estudios en el colegio inglés de Valparaíso, en el Seminario de Santo Tobirio en Lima y en el Convictorio de San Carlos hasta 1862. Empezó, pero no concluyó, la carrera de derecho en San Marcos. Con la eclosión la guerra del Pacífico (1879-1883), se alistó en el ejército de reserva y participó en la defensa de la capital. Participó en la creación del Círculo Literario de Lima en 1886 y del partido Unión Nacional en 1891, dedicados a la renovación de la literatura y la política en el Perú. Se destacó por la crítica corrosiva. Sus discursos en el Teatro Politeama (1888) criticaron a la corrupta clase política peruana, responsabilizándola por la derrota en la guerra con Chile. Después de una estancia en Europa, se acercó a los obreros y al pensamiento anarquista, en cuyos periódicos colaboró asiduamente. Fue director de la Biblioteca Nacional en 1912 y en 1916. (Milla Batres, 1994, pp. 85-88). 
González Prada escribió un artículo, en el mismo año de 1905, titulado Nuestras glorificaciones. La de Bolognesi, incluido en el libro que reunió parte de su producción, Horas de Lucha. La crítica de González Prada se dirigió a la representación del héroe en la clave del martirio y argumentó que el coronel parecía más un soldado borracho que un jefe mortalmente herido:

\begin{abstract}
¿Qué decir de la estatua, lo esencial del monumento? Bolognesi aparece cogiendo un revólver y asiéndose al asta de una bandera, como pudo figurar tocando un tambor o soplando una corneta. [...] La actitud de Bolognesi no expresa la resignación viril del militar que voluntariamente ofrenda su vida, sino la mansedumbre pasiva, la conformidad ovejuna. En vez del jefe herido y próximo a caer para no levantarse más, vemos al soldado que en día de francachela empuña el revólver del coronel, atrapa la bandera del batallón y va tambaleándose hasta rodar en tierra para dormir la crápula. Le vemos cómico y trágico, pues antes de ir al suelo, puede arrojar un tiro a cierta mujer que le brinda la imprescindible corona de laurel. ¡Infeliz Bolognesi! El plomo chileno le quitó la vida, el bronce queroliano le pone en irrisión (González Prada, 1905/1985, pp. 78-81)
\end{abstract}

Uno de los aspectos criticados por el escritor es la autoría extranjera de la obra. Acusó a los artistas europeos, en general, de actuar como empresarios exportadores, mirando sus obras como puro negocio de "exportación ultramarina":

Juzgando Taine a Corneille envejecido, afirmaba: "Ya no crea, fabrica". Fabricaciones, no creaciones, pueden llamarse las obras que generalmente nos mandan los artistas europeos. En Arte, como en modas, hay el artículo sudamericano. Querol sigue la regla: siendo capaz de un chef-d'euvre, se ahorra la faena de ejecutarle y nos elabora un artículo de exportación ultramarina. [énfasis agregado] (González Prada, 1905/1985, p. 78) 
De héroe mártir a héroe victorioso: intelectuales peruanos frente al monumento de Francisco Bolognesi y la tesis de un proyecto primitivo para el monumento

Sin embargo, no fue el texto de González Prada, escrito en 1905 delante del monumento ya inaugurado, el primer escrito publicado en el Perú que hacía una crítica a la presencia de artistas europeos en los certámenes americanos. Tres años antes, en 1902, en medio de la realización del concurso y exposición de los proyectos participantes para el monumento Bolognesi, el periódico El Comercio publicó una nota, sin indicación de autoría, cuestionando el conocimiento de los europeos sobre la realidad americana:

Es preciso, además, tener en cuenta que tratándose de obras relativas á [sic] América, ejecutadas por escultores y arquitectos europeos ese peligro es mayor, y puede decirse incalculable. Notorio es, en efecto, que los artistas más eminentes, y aún geniales de Europa, desconocen sin embargo, de un modo lamentable, la historia, los sucesos, los hombres, las cosas y los casos y las costumbres y hasta los rasgos étnicos de los países de América (El Comercio, 9 de abril de 1902, p. 1).

Después de la divulgación de Querol como vencedor del certamen -que ocurrió al día siguiente- este periódico no volvió a poner críticas ni cuestionamientos de este género. Luego, el autor desconocido de El Comercio y González Prada anunciaron, en principios del siglo XX, una cuestión que sería bastante debatida y polemizada por los críticos del arte e intelectuales americanos en la primera mitad de la centuria. En Brasil, en la década de 1920, en medio de las conmemoraciones del centenario de la independencia, lo vemos en un artículo de Monteiro Lobato, publicado en el diario $O$ Estado de São Paulo con relación a la apertura de un concurso para la erección de un monumento a los hermanos Andrada en Santos: "Desconhecedor da psicologia do povo e da significação íntima do tema a desenvolver em pedra e bronze, o artista exótico, por mais talento que possua, sempre faz sermão de encomenda" (Lobato, 14 de septiembre de 1920, citado por Pellegrini, 2000, p. 22). En la misma ocasión, 
se manifestó Menotti del Picchia con duras palabras, clamando por "Basta de made in Europe" (Del Picchia, 16 de septiembre de 1920, citado por Pellegrini 2000, p. 26).

En el Perú, una de las voces más críticas a la hegemónica presencia europea en la estatuaria limeña y defensora de la "nacionalización" de la escultura peruana fue la del crítico de arte y pintor Teófilo Castillo, estudiado por los trabajos de Fernando Villegas Torres (2006, 2010, 2015). Abordaremos los posicionamientos del crítico y pintor Castillo más adelante en este artículo.

En diciembre del mismo año de 1905, en el texto publicado anónimamente en Los Parias con el título "Las fiestas", González Prada volvió a movilizar la tinta y el papel contra el monumento a Bolognesi de Querol, tan celebrado por los intelectuales en los diarios y revistas limeñas. Sobra la estatua del héroe, el autor la caracterizó de "pieza montada", trabajo de "reposteros, confiteros y pasteleros".

Doblemente bobos merecen llamarse los que, extasiados y boquiabiertos, admiran el monumento de Bolognesi, como una obra maestra de la escultura española. En nuestra humilde opinión, la estatua, la columna y todos los accesorios se reducen a la materialización y petrificación de una poesía de Grilo revuelta con una novela de Pérez Escrich. La obra de Querol pertenece al arte escultural y arquitectónico de reposteros, confiteros y pasteleros: es una pieza montada. Si a Broggi, Klein y Nove les hubiéramos dicho: "Asóciense ustedes con el popular Cubillas $y$, usando los materiales del oficio, eleven un monumento a la gloria de Bolognesi”, estamos seguros que entre los cuatro nos habrían hecho una obra tan bella como la de Querol, no empleando sino el mazapán, el chocolate, el caramelo y el pan de dulce (González Prada, 1905/1941, pp. 119-120).

Aspecto anecdótico es que Querol fue hijo de un panadero y, según su biógrafo Rodolfo Gil, desarrolló su gusto por esculpir cuando sus dedos "hińen la levadura y con trozos de 
De héroe mártir a héroe victorioso: intelectuales peruanos frente al monumento de

Francisco Bolognesi y la tesis de un proyecto primitivo para el monumento

masa ensayan su afición en graciosas figurillas que fraguó su instinto" (Rodolfo Gil, 1910, p. 9).

Las críticas de González Prada, solitarias en 1905 cuando todos los intelectuales compartían el entusiasmo de la fiesta, ganaron nuevos adeptos en los años venideros. El escritor Pedro Dávalos y Lissón (1863-1942) ${ }^{14}$, en su libro Lima en 1907, publicado en 1908 con prefacio del alcalde Federico Elguera, en medio de elogios a los progresos de la urbanización de Lima, dejó registrada una nueva crítica al Bolognesi de Querol.

Es también nuevo para mí el monumento á Bolognesi. Su vista conmueve mi alma, despierta en ella las tristes realidades del pasado. El artista, feliz en los detalles de la columna, sublime en la cara que representa transida de dolor á la Historia después de grabar en la piedra la fecha de la epopeya, 1880, decae en la representación del héroe. Querol buscó para Bolognesi el supremo momento en que consuma su sacrificio, sin pensar que el arte está en la vida y no en la muerte. ¿Acaso no han llegado á su noticia, las dificultades que encuentran los misioneros católicos en China y en Japón, en su obra de propaganda, por la antiestética circunstancia de exhibir un Dios muerto en una cruz, siendo asi que para esos pueblos el Supremo Hacedor no puede nunca dejar de ser la Eterna Belleza y la Vida? [énfasis agregado]. (Dávalos y Lissón, 1908, p. 67) ${ }^{15}$.

14 Pedro Dávalos y Lissón empezó su formación en la escuela dirigida por Agustín de la Rosa Toro y en el Colegio de Guadalupe, y posteriormente estudió en la Facultad de Letras de San Marcos. Como reservista del Ejército, participó en la batalla de San Juan y Miraflores en enero de 1881. Después de la guerra con Chile, se dedicó a la minería y a las finanzas, y fue cónsul del Perú en La Habana entre 1902 y 1907. En el periodismo, fue corresponsal de El Comercio en Nueva York, y escribió artículos con el seudónimo de Donapeta. Fue miembro de la Sociedad Geográfica de Lima desde 1897. Incursionó en las investigaciones histórico-sociales escribió numerosos libros como Historia republicana del Perú, publicado en diez volúmenes entre 1931 y 1939 (Milla Batres, 1994, p. 33).

15 La referencia que me llevó a este libro de Pedro Dávalos lo encontré en el trabajo de Ramón Joffré (2013, p. 32). 
Para Dávalos y Lissón, la opción de Querol por representar el héroe en su momento agónico y no en su hora de gloria fue un error y, para ejemplificarlo, recordó la dificultad de los católicos en difundir el culto cristiano en oriente con la imagen de Jesús muerto en la cruz. La imagen del héroe como mártir está en el centro de su crítica.

En un artículo publicado en 1914 dedicado a exaltar un busto del coronel José Gálvez hecho por el escultor peruano David Lozano, Teófilo Castillo $(1857-1922)^{16}$ hizo fuertes críticas a la estatua del héroe en el monumento al Dos de Mayo (1874), hecho por el francés Cugnot, y cuestionó su representación como mártir moribundo, "mísero y simiesco". El articulista extendió su crítica al trabajo de Querol.

Y el resultado está visible: las mejores plazas de la capital se hayan ocupadas con obras en general medianísimas, exóticas, algunas hasta ridículas. A la triste colección que encabeza el héroe de Arica se ha agregado recientemente el monumento á [sic] Habich [...]. A la verdad que para haber salido con eso no valía la pena correr á [sic] Europa. (Castillo, 27 de junio de 1914, p. 901) ${ }^{17}$

Aunque la crítica de Castillo a las figuras de Gálvez y Bolognesi se concentre en la representación de los coroneles,

16 Teófilo Castillo, nacido en una familia terrateniente de Carhuaz que luego se trasladó a Lima, desarrolló parte de su formación en Europa. Fue pintor y uno de los más activos críticos de arte peruano de su tiempo, que publicó en revistas y periódicos. En 1906, empezó a trabajar como ilustrador de la revista Actualidades, donde también inauguró su trabajo de crítico con un artículo sobre Herminio Arias de Solís. De 1911 a 1913 realizó las portadas de la revista Ilustración Peruana y asumió después la dirección artística de la revista Variedades y del diario La Crónica, en los cuales también publicó sus artículos (Villegas Torres, 2006).

17 La referencia que me llevó a este artículo de Castillo se lo debo al trabajo de Villegas Torres (2010, p. 239). 
su punto está vinculado a la defensa que hace de la mayor presencia de artistas peruanos en la escultura monumental, mirando con esperanza al joven escultor autodidacta David Lozano, autor del busto al coronel del combate del Dos de Mayo, esperando que "sea él quien inicie en Lima la nacionalización de la escultura monumental" (Castillo, 27 de junio de 1914, pp. 900-901).

Completó esta primera ola de críticas un artículo sin autoría publicado en la revista ilustrada Variedades, en 1916, presentado en el artículo de Monteverde Sotil (2017, p. 694). El autor, respecto a la futura plaza y monumento a San Martín construidos para los festejos del centenario, da cuenta del supuesto rechazo generalizado a la obra.

Entendemos que una crítica especial ha estudiado el monumento contratado con Benlliure [Mariano Benlliure, escultor español encargado del Monumento a San Martín], y hacemos esta disquisición porque sería doloroso que sucediera más tarde lo mismo que sucede ahora con el de Bolognesi, que fué [sic] tomado é [sic] inaugurado entre verdaderos poemas de elogio al escultor y que, á [sic] medida que transcurren los años, se esmera la critica en encontrarlo feo, mal expresado, cursi y tantas otras cosas [énfasis agregado]. (Variedades, 1916, pp. 1537-1538).

\section{Segundo acto: la sustitución de la estatua del héroe}

Aunque el Ejército no haya tenido participación en la construcción del monumento - no había ningún membro militar en la comisión organizadora del concurso, presidida por el alcalde de Lima y compuesta por los ministros plenipotenciarios de EE. UU., Espańa, Bélgica, Italia y Francia, además de los concejales de Lima y del presidente de la Asamblea Patriótica Bolognesi, conforme la cuarta cláusula de las bases 
(El Comercio, 3 de julio de 1901, p. 2)- el mismo ańo de 1905 marca una primera aproximación de la institución con el monumento y la plaza Bolognesi. El 8 de noviembre de 1905, dos días después de la inauguración del monumento, el presidente José Pardo promulgó el siguiente decreto:

El juramento de fidelidad á [sic] la bandera, se prestará á [sic] los conscriptos del ejército el primer domingo del mes de junio de cada año, en ceremonia pública y solemne, que se realizará en Lima al pié [sic] del monumento erigido á [sic] la memoria del coronel Bolognesi y de sus compañeros de armas en la gloriosa defensa de Arica. Dado en Lima, á [sic] ocho de noviembre de mil novecientos cinco (El Peruano 28 de noviembre de 1905: 494).

En los años subsecuentes, anualmente se celebraría la jura a la bandera peruana en las condiciones señaladas por el decreto de Pardo. Asimismo, dos decretos del presidente Augusto B. Leguía ampliarían aún más esta vinculación del espacio de la plaza con la institución militar. En 1923, el presidente del oncenio decretó que la ceremonia debería ocurrir en el mismo día de la batalla, o sea, el 7 de junio -y no más en el primer domingo- (El Peruano, 1 de junio de 1923, p. 481), y en el año siguiente estableció esta fecha como Día de la Bandera. Así que la plaza Bolognesi y su monumento estuvieron definitivamente vinculadas a una fecha patriótica y a un ritual anual del Ejército (El Peruano, 20 de mayo de 1924, p. 469).

De hecho, el Ejército asumió la custodia de la memoria del héroe, siendo responsable -a través, del Centro de Estudios Histórico-Militares del Perú- por la publicación de gran volumen de obras historiográficas sobre la figura de Bolognesi, la batalla de Arica y la guerra del Pacífico de manera más amplia. Obra cumbre de esa producción respecto al monu- 
De héroe mártir a héroe victorioso: intelectuales peruanos frente al monumento de Francisco Bolognesi y la tesis de un proyecto primitivo para el monumento

mento a Bolognesi es La epopeya del morro de Arica (1980), en conmemoración del centenario de la batalla.

La definitiva apropiación del héroe y de su monumento y plaza por el Ejército tuvo lugar en la década de 1950, en el gobierno militar de Manuel Odría (1948-1956), cuando el coronel Bolognesi fue elevado al rango de Patrono del Ejército del Perú en enero de 1951 y alcanzó posteriormente el título de Gran Mariscal del Perú en noviembre de $1989^{18}$. El presidente Odría, permeable a la demanda de los militares, promulgó un decreto en junio de 1951 que determinó la sustitución de la estatua del coronel de Arica que coronaba el monumento. Según el Diario Oficial El Peruano, dicho decreto fue leído en la ceremonia de la jura de la bandera el 7 de junio de 1951. Se justificó la decisión del reemplazo por ser la obra original incongruente con la figura del héroe.

El coronel José Vallejos, Jefe del Gabinete Militar, dió [sic] lectura asimismo, al Decreto Supremo convocando a un concurso para reemplazar en el monumento a Bolognesi, la actual figura del héroe por otra que esté en consonancia con la actitud gallarda y heroica que lo nimbó de gloria en la epopeya de Arica (El Peruano, 8 de junio de 1951).

Fue elegido vencedor de este concurso el escultor peruano Artemio Ocaña (1894-1980) ${ }^{19}$, cuya escultura retrató a Bo-

18 Ley N. 25.128, "Confiere, a título póstumo, la dignidad de Gran Mariscal del Perú al héroe máximo, y Patrono del Ejército, coronel don Francisco Bolognesi, inmolado en la épica jornada de Arica”. Archivo Digital de Legislación Peruano.

19 Artemio Ocaña (1894-1980) fue escultor, discípulo de Libero Valente en la Escuela de Artes y Oficios de Lima (1915), hizo sus estudios en la Academia Concha (1917) y en la Real Academia de Bellas Artes de Roma, con Ettore Ferrari. Al regresar al Perú, fue profesor de la Escuela de Artes y 
lognesi en pose considerada honrosa: con el cuerpo erecto, dando un paso adelante en posición de marcha, con el brazo arriba suspendiendo la bandera nacional. La estatua de Querol fue, entonces, trasladada al Museo Real Felipe del Callao, donde se encuentra hasta hoy.

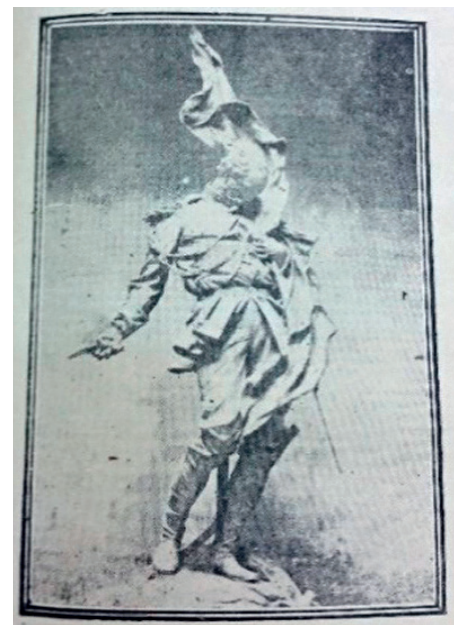

Figura 10. estatua de Bolognesi realizada por Querol (El Comercio, 5 de noviembre de 1905). Instituto Riva-Agüero

Oficios de 1922 a 1936. Entre sus trabajos en la capital del Perú, ejecutó el monumento a Petit Thouars, a la campańa de 1941 y un tríptico de relieve de bronce en la fachada del Ministerio de Economía y Finanzas (1953). Obtuvo un premio Concha en 1918 por su cabeza de negro y una medalla de la academia de Nápoles en 1970 (Milla Batres, 1994, p. 165). 
De héroe mártir a héroe victorioso: intelectuales peruanos frente al monumento de Francisco Bolognesi y la tesis de un proyecto primitivo para el monumento

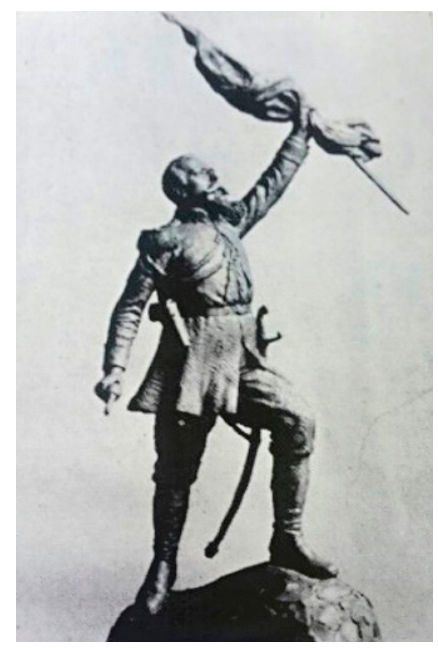

Figura 11. Estatua de Bolognesi realizada por Ocańa (Turismo, abril-mayo de 1954). Biblioteca Nacional de Perú

En el contexto de la inauguración de la nueva estatua, los debates acerca de ella volvieron a la orden del día. Entre los que se manifestaron, estuvo el entonces joven redactor de la revista Turismo, recién ingresado en la Universidad Nacional Mayor de San Marcos, Mario Vargas Llosa (1936-) ${ }^{20}$. Años

20 Laureado escritor peruano, Vargas Llosa nació en Arequipa en 1936. Ingresó en la Universidad Nacional Mayor de San Marcos, mientras trabajaba en diversos empleos para sostenerse -periodista radical, reportero del diario La Crónica, asistente del historiador Raúl Porras Barrenechea, etc. En 1958, obtuvo la beca Javier Prado Ugarteche, concedida anualmente por el Banco Popular al mejor egresado de Literatura de San Marcos, para seguir el posgrado en España. Incursionó en la política y se presentó como candidato presidencial en las elecciones de 1990, que perdió. Tras su derrota, se retiró del Perú y obtuvo la ciudadanía española. Recibió múltiples premios en su trayectoria, como Leopoldo Alas Clarín (1959), Biblioteca Breve (1962), Rómulo Gallegos (1967), Príncipe de Asturias de las Letras (1986), Miguel de Cervantes (1994) y el Premio Nobel de 
después, en un libro de perfil autobiográfico, El pez en el agua (2016), el escritor se acordó de este episodio y calificó la decisión del gobierno de un "acto de barbarie" y a la obra de Ocaña como un "grotesco monigote".

En el artículo En torno a una escultura, publicado en la revista en 1954, Vargas Llosa calificó el decreto de Odría y la nueva estatua de Ocaña de "mutilación" y "decapitación de un monumento". Para afirmar el absurdo desde el punto de vista artístico, el autor relató el supuesto rechazo, por parte de los artistas, al decreto de Odría en 1951. Según Vargas Llosa, este decreto suscitó un debate entre escultores en el diario limeño La Noche, en el que se manifestaron posiciones contrarias a la intervención, tanto de los defensores de la obra de Querol, Victorio Macho y Cervantes Murillo, como de los críticos y detractores, Espinoza Cáceda y Artemio Ocaña -para estos últimos, el concurso debería reemplazar todo el monumento de Querol, y no solo la estatua de la cúspide (Vargas Llosa, abril-mayo de 1954).

Además de exponer las críticas generales dirigidas a la decisión presidencial -incluso del propio futuro autor de la nueva escultura-, Vargas Llosa narró su visita al atelier de Ocaña y su entrevista con el artista, que le presentó las razones que justificaban el cambio de las estatuas. Las palabras de Ocaña concuerdan con el discurso oficial, de que el héroe militar peruano debería estar en pose marcial en su monumento.

Es poco edificante que las tropas presten su juramento ante la efigie de un moribundo, que el ejemplo que puedan ex-

Literatura (2010); es el escritor peruano de mayor prestigio internacional en la contemporaneidad (Milla Batres, 1994, pp. 125-129). 
De héroe mártir a héroe victorioso: intelectuales peruanos frente al monumento de Francisco Bolognesi y la tesis de un proyecto primitivo para el monumento

traer los futuros guerreros de un hombre que está en actitud de abatimiento, de pasividad, es poco sustantivo y más cercano a la desmoralización que a la belicosidad -tan dramáticamente buscada- y que en fin es necesario sustituir aquel trágico halo que la figura de Bolognesi esparce en derredor, por una estela de marcialidad, ejemplarizadora y gloriosa. [énfasis agregado] (Vargas Llosa, abril-mayo de 1954)

Luego, Vargas Llosa presentó, con mayores detalles, el principal argumento del escultor: la estatua de Bolognesi era anacrónica, expresión de un tiempo ya pasado.

Cuando se inauguró el monumento al héroe de Arica, en 1905, la expresión unánime estuvo de acuerdo en que aquella concepción pesarosa y agnóstica era la que correspondía a la historia y al sentimiento popular. El país, cercano todavía los destellos de la guerra fratricida, [...] prefería, en los sucesos acaecidos, insistir sobre aquellos detalles que pudieran hacerle llorar sobre sí mismo con más fuerza, como buscando así, un continuo afán de cólera, un motivo permanente de ira. [...]. Pero los ańos han ido borrando uno a uno aquel sentir decadente y romántico. A la inseguridad, propia del desconcierto primero, ha sucedido un nuevo espíritu, más real, proyectado de lleno al porvenir, con fe en sí mismo y con ideales asentados en una personalidad bien definida. Viene entonces la revisión de lo pasado, el rechazo a los antiguos errores - un hombre que sonríe desprecia su llanto de tres horas atrás- y la necesidad imperiosa de subsanarles, desprendiéndose de lastres contradictorios con su nueva cosmovisión, desanudando ataduras que le liguen a medrosismos [sic] opuestos al actual encaramiento viril de los problemas (Vargas Llosa, abril-mayo de 1954)

Después de esa exposición, el autor se interrogó: “¡Y el Arte? - me pregunto yo. - ¿Nada tiene que ver el Arte en este juego?" [énfasis agregado]. A continuación, lamentó la no consideración del valor estético de la estatua de Querol, entre 
aquellos responsables por la intervención en la obra: "Estaba demás que, después de aquello me inquiriese yo sobre si al arte le cabía alguna intromisión en las mutaciones de las cuales provendrá lo que sólo puede llamarse mutilación de una pieza escultórica” (Vargas Llosa, abril-mayo de 1954).

En las palabras de Ocaña transcritas por Vargas Llosa, la intervención en la obra escultórica se justificaba por el cambio de sensibilidad generalizado frente a ella: el sufrimiento, que había sustentado la representación del héroe como mártir, ya estaba superado. Por un lado, la definición de la cuestión de Tacna y Arica, con la reintegración de la primera a la nación en 1929, contribuyó para cerrar el capítulo de la guerra del Pacífico en la diplomacia peruana. Por otro, una nueva campaña militar victoriosa para el Perú, como la del Ecuador en 1941, contribuyó para desactualizar la retórica lastimosa y afirmar el poder bélico de las Fuerzas Armadas peruanas (Contreras y Cueto, 2013, pp. 291-293), lo que exigía un patrono al Ejército a la altura de su grandiosidad. Es importante señalar que Ocaña también fue el responsable de un conjunto monumental en homenaje a la guerra contra Ecuador, en el Campo de Marte, distrito de Jesús María, Lima (1943). De hecho, la vigencia de un gobierno militar, con mayores poderes, fue un aspecto que facilitó la intervención sobre la escultura ignorándose las posiciones contrarias autorizadas.

Artemio Ocaña, por su parte, por medio de un folleto publicado alrededor de 1959, que reunió textos antiguos y de distintos orígenes, buscó relatar el proceso de construcción e intervención en el monumento, con el objetivo de rebatir las críticas que recibió, especialmente de Vargas Llosa, y 
De héroe mártir a héroe victorioso: intelectuales peruanos frente al monumento de Francisco Bolognesi y la tesis de un proyecto primitivo para el monumento

defender la legitimidad de su obra ${ }^{21}$. Entre los documentos reunidos y transcritos por el autor, estuvieron un artículo de la revista Prisma de noviembre de 1905, contemporáneo a la primera inauguración; su entrevista personal para el diario La Noche, de junio de 1951; el decreto supremo de Odría y la resolución ministerial que decidieron la sustitución de la escultura en 1951; un texto de su propia autoría, "Referendum popular consagra la obra escultórica de Ocaña y aplaude a sus gestores"; y la transcripción del artículo de González Prada Nuestras glorificaciones. La de Bolognesi, ya mencionado en este texto.

En su defensa, Ocańa argumentó que las críticas al Bolognesi de Querol surgieron en las calles de Lima en su primera inauguración, desde que se descorrió el velo que cubría la estatua. Afirmó haber acompañado las fiestas a los once años y que escuchó: "el Bolognesi del monumento parece borracho" [énfasis agregado]. Ocaña también reservó una crítica especial al escultor catalán: "Un genial escultor, pero un superior comerciante" (Ocaña, 1959, pp. 11-12). En respuesta a las críticas que surgían en contra de su obra, Ocańa los acusó de solo manifestarse en aquel tiempo -1959- por razón de la salida del presidente Odría (1946-1958), llamándoles "resentidos" y "enemigos políticos" del expresidente. Sin embargo, los desafió, revelando la confianza en la popularidad de su obra: "En todo caso, ¿por qué no se 90 hace un plebiscito nacional? Voz populi, voz dei”.

Vemos que el artista peruano movilizó argumentos semejantes a los críticos que le antecedieron y acusó al artista extran-

21 No he encontrado mayores informaciones sobre la publicación y distribución de este material, que cuenta con solo una copia en la Biblioteca Nacional del Perú. 
jero de no ser un legítimo intérprete del héroe nacional y ser más bien un "comerciante" interesado en el lucro monetario. Buscó abrigarse bajo el manto legitimador de González Prada, cuyo artículo transcribió para afirmar el inmediato rechazo a la escultura de Querol.

\section{La tesis del proyecto primitivo}

Los años 50, además de agitados por el reemplazo de las esculturas y la polarización de posiciones frente a ellas, fueron también probablemente el punto de partida para la difusión de una controvertida tesis sobre el monumento hecho por Agustín Querol: que hubo un proyecto primitivo no ejecutado por el artista.

Hasta donde mis investigaciones me han llevado, uno de los primeros en presentar esa versión fue Vargas Llosa en su artículo En torno a una escultura, publicado en 1954 en la revista Turismo. Allí, el escritor añadió la fotografía de un proyecto distinto del ejecutado por el catalán, que exhibe un numeroso grupo de personajes en el pedestal y presenta al héroe en posición corporal distinta, sosteniendo en alto la bandera peruana. Dicha fotografía estaba acompañada de la siguiente leyenda:

La magnífica maquette -amplia y feliz interpretación de la epopeya del morro- que presentó Querol al concurso y que lamentablemente no pudo ser elegida, al parecer, por razones de índole económica. Como se ve, se trata de una exaltación épica que atañe a todo el conjunto. Y de composición simétrica: las figuras que se desbordan hacia la izquierda y hacia el basamento hallan su justo balance en la efigie del héroe, separada, de la bandera que tremola en alto (Foto de la monografía de Agustín Querol por Rodolfo Gil) (Vargas Llosa, abril-mayo 1954). 
Vargas Llosa afirmó que el artista premiado por la comisión organizadora del concurso organizado entre 1901 y 1902 fue Mariano Benlliure, cuyo proyecto no fue realizado debido a su elevado presupuesto. Según Vargas Llosa, Benlliure se retiró del concurso por pedido de la comisión organizadora para que él hiciera una reducción en su obra a fin de rebajar su costo. Entre los artistas que quedaron, se eligió el proyecto Salve patria fides de Querol, que sí aceptó hacer una reducción en su trabajo. Sobre ese proceso, sin presentar fuentes documentales, pero aparentemente reproduciendo un discurso difundido en la época, Vagas Llosa dijo:

Hay un hecho que anotar en ese momento, porque últimamente en relación con la nueva escultura, se ha mencionado con insistencia un proyecto de Monumento a Bolognesi, de Querol, cuya concepción es por completa opuesta a la que se va a destruir. Aparece allí el héroe en la cúspide de un cuadro heroico -Alfonso Ugarte está a caballo, antes del trance eterno, mientras a su alrededor una multitud bravía se desborda en arranque de belicosidad manifiesta, a lo largo de plataformas intermedias y aún sobre los basamientos [sic] -en posición de marcialidad y vida, tal como lo quiere el decreto. En efecto, dicha maquette fué [sic] la premiada, pero su elevado precio hacía imposible su realización. La dificultad fué [sic] resuelta por Querol, que presentó un nuevo proyecto, amoldado a las posibilidades económicas de la Asamblea. Y el nuevo proyecto significó a la vez, un cambio completo de concepción, ya que entre el ambiente histórico sobre el que se yerguen ambos monumentos - del Bolognesi que revive al que agoniza y del Alfonso Ugarte que cabalga al que rueda al abismo- existen diferencias diametrales de percepción del hecho, diferencias de exégesis. Aparte de esta diferencia, entre ambos monumentos, quedaba sin embargo una sola línea de belleza -reverberante de épica la una, trágica y desoladora la otra [énfasis agregado] (Vargas Llosa, abril-mayo 1954). 
Artemio Ocańa, en su folleto publicado en 1959, reprodujo las cuestiones levantadas por Vargas Llosa, aunque con la explícita intención de descalificar la escultura de Bolognesi hecha por Querol y defender su obra, inaugurada cinco años antes. Para defenderse de la crítica por una "mutilación" en la obra de arte, el escultor peruano argumentó que su trabajo se filiaba a la concepción original del propio artista catalán, siendo que la mutilación había sido hecha por la comisión organizadora del concurso, que impuso a Querol un completo cambio en su proyecto, que le quitó su grandiosidad primitiva.

El resultado fue de esperarse [...]. Querol debía hacer la transformación de su maqueta, reduciendo sus proporciones en grande parte y cambiando la actitud gallarda y arrogante en su primitivo proyecto, por otra, a gusto de la comisión de entonces, que todavía sentía el tremendo peso de la derrota y la tiranía de la soldadesca chilena que durante 3 años dominaron el Perú (Ocaña, 1959, p. 10).

Posteriormente, dicha tesis fue reproducida por Felipe de la Barra, general del Ejército peruano, en un libro dedicado a los monumentos escultóricos de Lima y el Callao (1963). La narrativa presentada por Vargas Llosa y seguida por Ocańa fue, nuevamente, repasada por el general, mientras elogiaba el hecho de que la obra original había sido preservada en el Museo Real Felipe del Callao, y no hundida o destruida, gracias a la intervención del Centro de Estudios HistóricoMilitares del Perú:

Vale la pena hacer breve reseña que en el fondo destacará la constante preocupación del CEHMP por mantener el acervo histórico-patriótico peruano. En efecto, apenas se produjo el cambio, la institución solicitó al Ministerio de Guerra que la estatua retirada, y que había sido trasladada a los talleres del Arsenal de Guerra, fuese entregada al Museo Histórico Militar, que es organismo integrante del 
De héroe mártir a héroe victorioso: intelectuales peruanos frente al monumento de Francisco Bolognesi y la tesis de un proyecto primitivo para el monumento

CEHMP, por ser su lugar indicado. La gestión, sin embargo, fue desatendida, habiéndose nos contestado que la estatua sería fundida para fabricar pequeñas réplicas del nuevo monumento que se distribuirán en las altas reparticiones del Ejército. Nuestra reacción fue naturalmente enérgica e inmediata, y es así que en mi condición de presidente del CEHMP, y como tal responsable del cumplimiento de su función institucional, gestioné personalmente ante la autoridad competente la revogación [sic] de aquella disposición de fundir la estatua, y que siempre se nos la entregara, exponiendo como principal argumento, aparte del valor artístico, "de que ante ella habíamos jurado cincuenta promociones, desde la egresada de 1906, y miles y miles de contingentes de tropas" (De la Barra, 1963, p. 17).

Finalmente, la tesis del proyecto primitivo apareció en trabajos académicos peruanos, sin compromiso de defender la intervención en el monumento, incluso en obras clásicas, como la Historia de la República del Perú de Jorge Basadre (edición de 1983, p. 169), e investigaciones más contemporáneas, como la tesis de maestría de Víctor Mejía Ticona (2013, p. 48).

Sin embargo, ninguno de los autores mencionados presentó en sus textos una referencia documental que comprobara la existencia de dicho "proyecto primitivo", alterado por imposición de la comisión organizadora. El artículo de Vargas Llosa incluyó, al pie de la fotografía del supuesto proyecto primitivo, la referencia de donde había sacado la imagen, que era la obra de Rodolfo Gil, una biografía de Agustín Querol publicada luego de su muerte, en 1910. No obstante, en la obra de Gil, esta fotografía aparece con la leyenda "Proyecto de monumento", sin mención de que fuera un proyecto primitivo del monumento a Bolognesi (Gil, 1910, lámina XXV). 


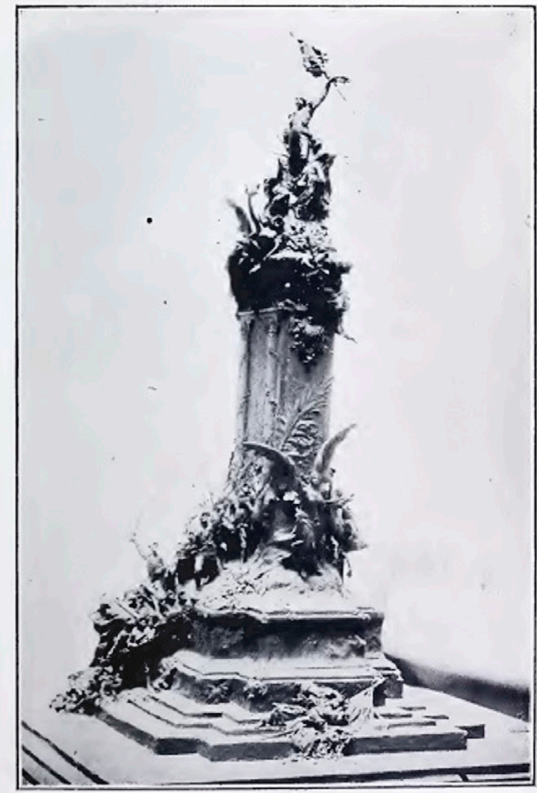

Proyecto de monumento

Propet ife monument.

Figura 12. Proyecto de monumento. Gil, 1910. Lámina XXV

En cuanto a las fuentes documentales disponibles, no he podido encontrar nada que compruebe la tesis de un proyecto primitivo. En el diario El Comercio, se menciona que la apertura de la exposición de proyectos tuvo lugar el día 31 de marzo de 1902, "en uno de los almacenes de la casa del señor Du Bois" (El Comercio, 1 de abril de 1902, p. 2). Según el mismo periódico, la comisión organizadora del concurso celebró su primera reunión el 3 de abril de 1902, a las cinco de la tarde (El Comercio, 3 de abril de 1902, p. 2). El 7 abril, la comisión volvió a reunirse para analizar las propuestas y decidió una nueva reunión para el 9 de abril (El Comercio, 8 de abril de 1902, p. 2). Por fin, el día 10 de abril, El Comercio anunció el nombre del ganador, decidido por mayoría de 
siete votos en la reunión del día anterior: Salve patria fides del catalán Agustín Querol. El periódico presentó una descripción del proyecto, que corresponde a la obra ejecutada por el artista, con el héroe enrolado en la bandera: "parece que diera un paso adelante y que estuviera como envolviéndose en el pabellón de la patria que aprisiona contra su corazón" [énfasis agregado] (El Comercio, 10 de abril de 1902, p. 1). Conforme el articulista, no hubo pleno consenso dentro de la comisión, siendo que los proyectos fueron objeto de intensos debates en sus reuniones, revelando que la materia no estaba definida con anterioridad: "Antes de adoptar esta resolución, el jurado discutió larga y calurosamente el asunto" (El Comercio, 10 de abril de 1902, p. 1).

Hay que considerar que el artista catalán no viajó al Perú para acompańar el concurso y toda comunicación entre él y las autoridades peruanas debería ocurrir por cartas, que llevarían mucho tiempo para cruzar el Atlántico, o por medio del cable telegráfico, aunque con la mediación y apoyo del Ministro Plenipotenciario español en Lima, Gil de Uribarri. No hemos encontrado en el Archivo del Ministerio de Relaciones Exteriores, documentación que compruebe la existencia de dicha comunicación antes de la divulgación del resultado del concurso. Después del triunfo del artista catalán, el 10 de abril, El Comercio notició que el alcalde de Lima Federico El-

96 guera, el ministro Gil de Uribarri y el presidente de la Asamblea Bolognesi, José Oyague y Soler enviaron telegramas al escultor felicitándole por su triunfo (El Comercio, 10 de abril de 1902, p. 1).

Considerando que el artista catalán no viajó al Perú para acompañar el concurso, el tiempo que demandaría la comunicación entre ambas partes y el envío de un nuevo proyecto, 
hay que reconocer que no hubo tiempo hábil para que el artista hiciera una remodelación con su nueva concepción, tan pocos días después de las reuniones de la comisión organizadora.

Por otro lado, El Comercio anunció, antes del anuncio de la decisión del jurado, que Querol no había enviado solo uno, sino por lo menos cuatro proyectos al certamen, todos con el seudónimo Salve, patria fides.

Bueno sería, ya que se ha sentado ese precedente, que la asamblea Bolognesi mandara ampliar, para que puedan apreciarse en todo su mérito, las fotografías de los trabajos del célebre escultor Querol, quien ha enviado cuatro proyectos más cuyos precios fluctúan entre 150.000 á 400,000 fran$\cos$ (El Comercio, 8 de abril de 1902, p. 2).

Así también lo hizo el periódico cuando anunció la victoria del catalán:

Son muchos los proyectos que ha presentado Querol, á cual de ellos más hermosos y más atrevidos como concepción artística. En todos, se nota ese admirable buen gusto, esa grandeza del concepto y esa elegancia nerviosa de la ejecución, que tan justa celebridad han dado al escultor catalán (El Comercio, 10 de abril de 1902, p. 1).

Esto no fue una excepción en la trayectoria profesional del artista; él mismo volvería a hacerlo en 1906, cuando presentó cuatro proyectos con el seudónimo Libertas para el concurso del monumento a San Martín en Lima (Klingsor, 1906). Tampoco Querol fue el único, pues el italiano Giuseppe Tadolini envió dos proyectos nombrados Roma 1 y Roma 2 ( $E l$ Comercio, 30 de diciembre de 1901, p. 1). Por un lado, el envío de múltiples proyectos no estaba vetado en las bases del concurso. Por otro, puede explicarse por la no definición, en 
De héroe mártir a héroe victorioso: intelectuales peruanos frente al monumento de Francisco Bolognesi y la tesis de un proyecto primitivo para el monumento

las mencionadas bases, del costo máximo ni mínimo que los proyectos deberían tener, de modo que los artistas consideraron distintos presupuestos en sus diversos proyectos.

Ante esta situación, propongo que la fotografía de la maqueta presentada por Vargas Llosa no se trataría de un proyecto primitivo anterior al proyecto premiado por la comisión organizadora, sino que estos fueron enviados simultáneamente por el artista catalán para el concurso, siendo dos de los cuatro proyectos mencionados en El Comercio.

De hecho, hay dificultad para avanzar de manera definitiva respecto a los proyectos de Querol para el monumento a Bolognesi, por lo que mi hipótesis también tiene sus límites. Debemos reconocer, por ejemplo, la posibilidad de que el modelo presentado por Rodolfo Gil y reproducido por Vargas Llosa pertenezca a otro proyecto del escultor catalán, sin relación con el certamen peruano. El atelier de Querol en el Paseo del Cisne en Madrid, que reunía las maquetas y bocetos del artista, se desmanteló después de su muerte en 1909, sin que la promesa de construir un museo para él se concretara ni en Madrid ni en Tortosa, su ciudad natal (Gunda López, 2009). De este modo, la biografía de Gil es una de las únicas fuentes documentales para conocer los trabajos del catalán.

Como señaló Virgilio Cabanillas Delgadillo (2017), el monumento a Bolognesi ejecutado por Agustín Querol compartió muchos lineamentos comunes con un proyecto anterior del artista, presentado a un concurso en Madrid en 1901 para construcción de un monumento al rey español Alfonso XII. De ese proyecto no realizado, Querol aprovechó la concepción general: la figura alada de la Fe delante del pedestal, con un brazo arriba; las figuras de la Fama con su trompeta y de la 
Gloria con los laureles junto al capitel, alrededor del héroe; el diseño del pilar, con una hoja de palma sobre él. Sin embargo, el otro proyecto de Querol, derrotado en el concurso limeño, que Vargas Llosa presentó como primitivo, tiene aún más semejanzas con la propuesta de Querol para el certamen madrileño: un gran grupo de soldados con sus espadas en alto se distribuye por el basamento. Concluimos que el proyecto de Querol elaborado para el Alfonso XII en Madrid en 1901, derrotado en el concurso, sirvió de punto de partida e inspiración para los distintos proyectos que presentó al concurso del monumento de Bolognesi en el año siguiente.

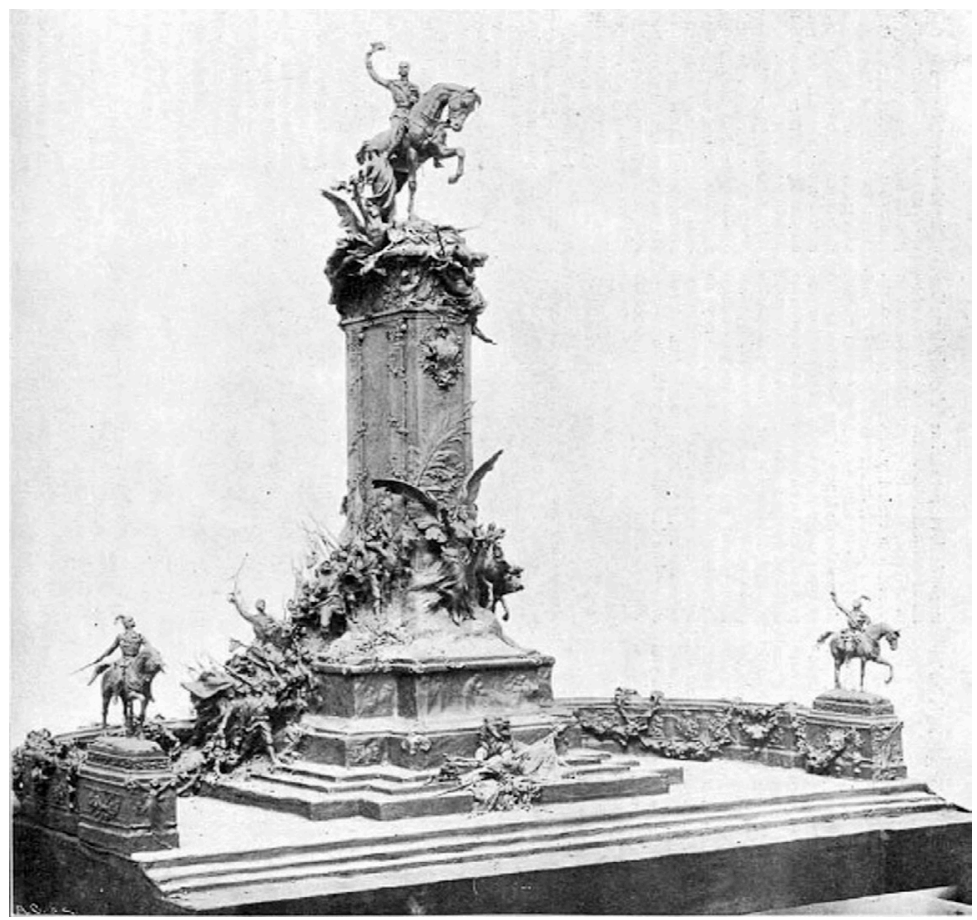

Figura 13. Concurso de estatua ecuestre que perpetúe la memoria del rey Alfonso XII. La Ilustración Española y Americana, 22 de junio de 1901, p. 373 
De héroe mártir a héroe victorioso: intelectuales peruanos frente al monumento de Francisco Bolognesi y la tesis de un proyecto primitivo para el monumento

Aunque en las fuentes primarias no encontremos mención a un proyecto originario, ni tampoco a la participación de Mariano Benlliure ${ }^{22}$ en el concurso, como hemos visto, esta tesis disfrutó de cierta popularidad. Considerando su probable fecha en la década de 1950, propongo que su aparición y difusión estuvo relacionada con el propio esfuerzo del gobierno peruano y después del escultor Ocaña por descalificar la estatua de Bolognesi hecha por Querol y legitimar la intervención en el monumento. Además, la tesis del proyecto primitivo tenía una importante ventaja: atribuía a la comisión organizadora del concurso, vinculada a los tiempos de la infame república aristocrática y del Partido Civil, la mutilación del monumento, no a los actores políticos del presente ni al artista Querol -aunque este haya aceptado reconstruir su proyecto-, lo que justificaría el reemplazo de la primera estatua de Bolognesi, pero la conservación de los otros grupos del conjunto escultórico realizado por el catalán.

Hoy, el Bolognesi de Querol sigue en el Museo Real Felipe, en un sitio relativamente marginal de su itinerario, basta señalar que al pasar la puerta de acceso al museo se ve primero una copia de la nueva estatua de Bolognesi hecha por Ocaña.

22 Según las bases del concurso, los artistas participantes debieron enviar sus proyectos con un seudónimo, por lo que la identidad de la mayoría de los 153 candidatos se desconoce; el número final de proyectos participantes fue informado en la Memoria de la Municipalidad de 1902 (1903, p. 39). Sin embargo, el diario El Comercio, antes de la divulgación del fallo del jurado, presentó los nombres de distintos escultores participantes, como los del francés Paul Aubé, de los italianos Alessandro Biggi, Luis Gicchero y Giulio Tadolini, y del español Querol. Con la divulgación de los otros premios, sabemos que también enviaron proyectos el francés Charles Perron y el italiano Ricardo Secchi. En ninguna fuente primaria conocida se mencionó el nombre de Benlliure. 


\section{Conclusión}

He presentado en este artículo las distintas posiciones de intelectuales y artistas peruanos frente al monumento a Bolognesi, buscando interpretar sus contenidos a la luz de los contextos y compromisos ideológicos y profesionales. Asimismo, he buscado identificar, en esta corta reflexión, los aspectos que hicieron posicionarse a intelectuales y artistas delante del monumento a Bolognesi, y las tensiones y disputas respecto a su autoría nacional o extranjera, la pose digna o indigna de un héroe y la defensa del arte.

El punto común de estos distintos actores -ya sea los que se manifestaron en defensa u oposición a la obra y su intervención- fue el deseo de intervención en la realidad y el sentirse autorizados por sus saberes para defender los valores considerados legítimos y resguardar a la cultura contra un "acto de barbarie", como lo calificó Vargas Llosa, o la honra del héroe contra la "efigie de un moribundo", como dijo Ocaña.

Podemos constatar cómo los discursos o posicionamientos fueron rescatados y reapropiados en nuevos contextos con la finalidad de legitimar sus posiciones o descalificar las del interlocutor. Así, Artemio Ocaña decidió transcribir el artículo de González Prada, contemporáneo a la inauguración, no solo para sostener su argumento de que las críticas a la escultura original fueron instantáneas, sino también para respaldar su trabajo con la autoridad intelectual del escritor. Por otro lado, Vargas Llosa buscó, en los debates de 1951, poner a Ocaña en contradicción al afirmar que este se había manifestado anteriormente en contra de la sustitución. 
En la década de 1950, estos discursos no solamente justificaron el desplazamiento de la estatua de Bolognesi hecha por Querol, sino que también manipularon la trayectoria pretérita de la obra, a fin de legitimar la intervención que se llevaba a cabo -aunque su probable primera manifestación registrada haya sido de un crítico a la nueva estatua, Vargas Llosa. Intenté demonstrar que la tesis de un proyecto primitivo para el monumento no se sostiene en pie, frente a la carencia documental.

Recibido: 15 de noviembre del 2018

Aprobado: 25 de mayo del 2019

\section{Referencias bibliográficas}

Actualidades: Revista Ilustrada.

1904 Lima, 2 (167), 7 de junio de 1905. Biblioteca Nacional del Perú.

1905 Lima, 3 (núm. extraordinario), noviembre-1905. Biblioteca Nacional del Perú.

1905 Lima, 3 (137), 11 de noviembre de 1905. Biblioteca Nacional del Perú.

1905 Lima, 3 (138), 18 de noviembre de 1905. Biblioteca Nacional del Perú (BNP).

Agulhon, M.

102

(1988) Histoire vagabonde, v. I. Paris: Gallimard.

Altamirano, C.

(2010) Introducción al volumen II. Élites culturales en el siglo XX latinoamericano”. En C. Altamirano (Dir.). Historia de los intelectuales en América Latina. V. II: Los avatares de la ciudad letrada en el siglo XX. Buenos Aires, Madrid: Katz Editores. 
Arthur, M.

(2002) Forgotten Voices of the Great War: A New History of WWI in the Words of the Men and Women Who Where There. Londres: Ebury Press.

Barentzen Gamarra, H.

(2010) El enigma de Gil: Gil de Castro, retratista. Revista del Museo Nacional, t. L., 173-192.

Barra, Felipe de la.

(1963) Monumentos escultóricos en Lima metropolitana y Callao y los grandes ausentes. Lima: Imprenta del Ministerio de Guerra.

Basadre, J.

(1983) Historia de la República del Perú, 1822-1933 (7. a ed. t. VIII). Sexto periodo: La República Aristocrática (1895-1919). Lima: Editorial Universitaria.

Berresford, S.

"I monumenti ai caduti". In: Berresford, S. (org.). Carrara e il mercato della scultura. $1^{\text {a }}$ ed. Milão: Federico Motta Editore.

Cabanillas Delgadillo, V. F.

(2017) Arte y nación. Escultura pública en Lima. Investigaciones Sociales, 21 (38), 127-137.

Carrillo, E. A.

Lo que significa el monumento. Actualidades: Revista Ilustrada (número extraordinario), noviembre

Casalino Sen, C.

(2008) Los héroes patrios y la construcción del Estado-nación en el Perú (siglos XIX y XX). (Tesis para optar el grado de doctora).-Universidad Nacional Mayor de San Marcos, Lima. 
De héroe mártir a héroe victorioso: intelectuales peruanos frente al monumento de

Francisco Bolognesi y la tesis de un proyecto primitivo para el monumento

Castillo, T.

(1914) A propósito del monumento a José Gálvez. Variedades: Revista Semanal Ilustrada, 10 (330), 27 de junio de 1914, 900-902.

Castrillón Vizcarra, A.

(1991) Escultura monumental y funeraria en Lima. En J. A. Lavalle, Escultura en el Perú. Lima: Banco de Crédito del Perú.

Chocano, J. S.

(1900) La epopeya del morro (poema americano). Premiado con medalla de oro por el Ateneo de Lima. "I. El canto de los héroes" y "IV. En espera". México: Maucci Hermanos, Primera del Rolex.

Cisneros, L. F.

(1905) Al descubrir el monumento. Actualidades: Revista Ilustrada, 3 (núm. extraordinario), noviembre.

Contreras, C. y Cueto, M.

(2013). Historia del Perú contemporáneo: desde las luchas por la independencia hasta el presente. Lima: Instituto de Estudios Peruanos, Pontificia Universidad Católica del Perú, Universidad del Pacífico.

Corpancho, T. E.

(1905) El triunfo de la Gloria. Actualidades: Revista Ilustrada, 3 (núm. extraordinario), noviembre.

104 Dávalos y Lissón, P.

(1908) Lima en 1907. Lima: Librería é Imprenta Gil.

El Comercio

1901 Bases para el concurso del Monumento á Bolognesi. Ed. de la tarde, n. 24.723, 3 de julio de 1901. Instituto Riva-Agüero. 
1901 Monumento á Bolognesi. Ed. de la mañana, n. 25.048, 30 de diciembre de 1901. Instituto Riva-Agüero.

1902 Monumento a Bolognesi. Ed. de la mañana, n. $25.209,1^{\circ}$ de abril de 1902 . Instituto Riva-Agüero.

1902 Monumento 'Bolognesi. n. 25.213, 3 de abril de 1902. Instituto Riva-Agüero.

1902 Monumento á Bolognesi. n. 25.222, 8 de abril de 1902. Instituto Riva-Agüero.

1902 Crónica. Monumento á Bolognesi. Ed. de la mañana, no 25.226, 10 de abril de 1902. Instituto Riva-Agüero.

1905 Ed. de la tarde, n. ${ }^{\circ}$ 29.882, 4 de noviembre. Instituto Riva-Agüero.

1905 Ed. especial de 16 páginas, no 29.883, 5 de noviembre. Instituto Riva-Agüero.

1905 No 29.884, 6 de noviembre. Instituto Riva-Agüero.

$1905 \quad$ Ed. de la tarde, no 29.887, 7 de noviembre. Instituto Riva-Agüero.

1905 Lima, ed. de la mañana, no 29.888, 8 de noviembre. Instituto Riva-Agüero.

El Peruano: Diario Oficial

1905 Ministerio de Guerra y Marina. Dirección de Guerra. Año 65, t. 2, semestre 2, no 48, 28 de noviembre de 1905. Instituto Riva-Agüero.

1905 "Poder Ejecutivo - La Jura de la Bandera. Año 82, t. 1 , semestre $1^{\circ}$, n. $120,1^{\circ}$ de junio de 1923 . Instituto Riva-Agüero.

1905 Poder Ejecutivo - Estableciendo en la República el Día de la Bandera. Año 83, t. 1, semestre $1^{\circ}$, n. 114 , 20 de mayo de 1924. Instituto Riva-Agüero.

1951 Lectura de un importante Decreto Supremo. No 3104, 8 de junio. Instituto Riva-Agüero. 
De héroe mártir a héroe victorioso: intelectuales peruanos frente al monumento de

Francisco Bolognesi y la tesis de un proyecto primitivo para el monumento

Fornis Vaquero, C.

(2013) Leónidas y las Termópilas: entre literatura, arte y propaganda. En Debita verba: estudios en homenaje al profesor Julio Mangas Manjarrés, v. 5, pp. 493-511. Oviedo: Universidad de Oviedo..

Gil, R.

(1910) Agustin Querol. Monografías de Arte, v. 5. Madrid: Sáenz de Jubera Hermanos.

González Prada, M.

(1941) Las Fiestas. Prosa menuda. Buenos Aires: Ediciones Imán, Sarmiento, Talleres Gráficos Argentinos L. J. Rosso.

González Prada, M.

(1985) Nuestras glorificaciones. La de Bolognesi. Paginas libres. Horas de lucha. Prólogo y notas de Luis Alberto Sánchez. Caracas: Biblioteca de Ayacucho, v. 14.

Gunda López, A.

(2009) El legado póstumo de Agustín Querol: su estudio madrileño, su museo no realizado ni en Madrid ni en Tortosa. Revista de la Asociación Aragonesa de Críticos de Arte, (9), dez.

Gutiérrez Viñuales, R.

(2003) Monumentos conmemorativos de escultores españoles en Iberoamérica (1897-1926). En M. Cabañas Bravo, (Coord.), El arte español fuera de España (pp. 355-366). Madrid: Consejo Superior de Investigaciones Científicas.

Gutiérrez Viñuales, R.

(2004) Monumento conmemorativo y espacio público en Iberoamérica. Madrid: Ediciones Cátedra. 
Hamann Mazuré, J.

(2011) Monumentos públicos en espacios urbanos de Lima: 1919-1930 (Tesis para optar el grado de doctora). Barcelona: Universidad de Barcelona.

Haskell, F. y Penny, N.

(2006) Taste and the Antique. The Lure of Classical Sculpture, 1500-1900. Londres: Yale University Press.

Hobsbawm, E.

(2012) A produção em massa de tradiçóes: Europa, 18701914. En E. Hobsbawn y T. Ranger (Eds.), A invenção das tradiçóes (2. $\left.{ }^{\mathrm{a}} \mathrm{ed}\right)$. São Paulo: Paz e Terra.

Hosiasson, L. J.

(2011) Nação e imaginação na Guerra do Pacífico. São Paulo:

Editora da Universidade de São Paulo.

Klingsor.

(1906) Monumento à San Martín. Sugestiones de Justus. La Prensa. Ed. de la tarde (1.558), 16 de mayo de 1906. Instituto Riva-Agüero.

La Ilustración Española y Americana

(1901) Concurso de estatua ecuestre que perpetúe la memoria del rey Alfonso XII. Madrid, año 45, n. 23, 22 de junio de 1901.

La Prensa.

(1905) Edición especial de inauguración (1.216), 6 de noviembre de 1905. Instituto Riva-Agüero.

Majluf, N.

(1994) Escultura y espacio público. Lima, 1850-1879. Lima:

Instituto de Estudios Peruanos.

Manrique, $\mathrm{N}$.

(1995) Historia de la Republica. Lima: Fondo Editorial de Cofide. 
De héroe mártir a héroe victorioso: intelectuales peruanos frente al monumento de

Francisco Bolognesi y la tesis de un proyecto primitivo para el monumento

Mejía Ticona, V. R.

(2013) Prefiguración de la Plaza San Martín y su monumento (1899-1921)Tesis para optar el grado de maestría en historia del arte. Pontificia Universidad Católica del Perú, Facultad de Arte, Lima.

Milla Batres, C. (Ed.).

(1994) Enciclopedia biográfica e histórica del Perú. Siglos XIX-XX (12 t.). Lima: Editorial Milla Batres S.A.

Mondońedo Murillo, P. C.

(2002) El retrato de José Olaya. La obra disímil de José Gil de Castro. (Tesis para optar el título de licenciado en arte), Facultad de Letras y Ciencias Humanas, Universidad Nacional Mayor de San Marcos, Lima.

Monteverde Sotil, R.

(2017) Política internacional de la posguerra del Pacífico, remodelación urbana y proyectos escultóricos de Lima: el monumento público a Francisco Bolognesi y los caídos en la batalla de Arica (1905). Historia, 2(50),.

Municipalidad de Lima

(1903) Memoria de la Municipalidad de Lima 1902. Monumento Bolognesi. Lima: Librería e Imprenta Gil. Biblioteca Nacional del Perú.

Ocaña, A.

Monumento en homenaje al héroe de Arica Coronel Francisco Bolognesi: reseña informativa de todo el proceso desde la elección de los proyectos del escultor catalán Agustín Querol, hasta el año de 1954, en que se reemplazó la estatua que coronaba el pedestal por otra ejecutada por el escultor nacional Artemio Ocaña. Lima, ¿1959?. Biblioteca Nacional del Perú.

Pellegrini, Sandra B.

(2000) Noticias de Brecheret. São Paulo: S.B. 
Prisma, Revista Ilustrada, de Arte, Letras, Etc.

(1905) Edición extraordinaria a la gloria de Francisco Bolognesi, 1 (número extraordinario), diciembre de 1905. Biblioteca Nacional del Perú.

Prost, A.

(1982) Les monuments aux morts: Culte républicain? Culte civique? Culte patriotique? En P. Nora, Les lieux de mémoire (v. 1. La République, pp. 195-225). Paris: Galimard.

Rama, Á.

(1985) A cidade das letras. São Paulo: Editora Brasiliense.

Ramón Joffré, G.

(2013) El Inca indica Huatica: simbología precolonial e intervención urbana en Lima, 1920-1940. En C. Aguirre y A. Panfichi (Eds.), Lima, siglo XIX. Cultura, socialización y cambio. Lima: Fondo Editorial PUCP.

Saldaña Niño, A. K.

(2018) La historia nacional en la pintura de Juan Lepiani. (Tesis para optar el título de licenciada en arte. Universidad Nacional Mayor de San Marcos, Facultad de Letras y Ciencias Humanas, Lima.

Stancik, M. (2003)

Imagens sentimentais, mensagens belicistas: o imaginário francês em postais pré Grande Guerra (1914-1918). Intercom - RBCC, 36 (2), 219-244.

Soares, G. P. (2000)

Projetos politicos de modernização e reforma no Peru: 1950-1975. São Paulo: Annablume, Fundação de Amparo à Pesquisa do Estado de São Paulo (FAPESP). 
De héroe mártir a héroe victorioso: intelectuales peruanos frente al monumento de

Francisco Bolognesi y la tesis de un proyecto primitivo para el monumento

Torres, J. L.

(1885) Catecismo patriótico y los mártires. Lima: Imprenta del Universo de Carlos Prince.

Vargas Llosa, M.

(1954) En torno a una escultura. Turismo: Revista Peruana de Viajes, Artes, Letras y Actualidad, XVIII (171), abril-mayo. Biblioteca Nacional del Perú.

Variedades: Revista Semanal Ilustrada.

(1916) La futura Plaza San Martín. Variedades (455). noviembre. Biblioteca Nacional del Perú.

Villegas Torres, F.

(2006) El Perú a través de la pintura y critica de Teófilo Castillo (1887-1922). Nacionalismo, modernización y nostalgia en la Lima del 900. Lima: Asamblea Nacional de Rectores.

Villegas Torres, F.

(2010) La escultura en el 900: entre la obra europea importada y la formación de la escultura nacional. Revista del Museo Nacional, 211-245.

Villegas Torres, F.

(2015) Vinculos artísticos entre España y el Perú (1892-1929). Elementos para la construcción del imaginario nacional peruano. Lima: Fondo Editorial del Congreso del Perú. 